Journal of Educational

and Psychological Sciences

Volume (5), Issue (2) : 30 Jan 2021

P: 1 - 23

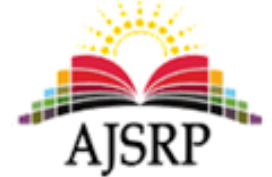

ISSN: 2522-3399

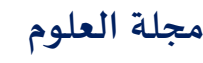

التربوية والنفسية

المجلد (5)، العدد (2) : 30 يناير 2021 م

ص: 1 - 13

\title{
Evaluating the Skills of Tajweed and Recitation of Holy Quran in the Primary Instruction Program - Specialization of Islamic Studies at Faculty of Education - University of Bisha
}

\section{Osman Mohamed Hamid Elaalim}

\section{Mohammed Yousif Ahmed Elsanosi}

\author{
University of Bisha $\|$ KSA
}

University of the Holy Quran and Islamic Sciences \| Sudan

\begin{abstract}
The research aims to identify the degree to which student teachers at the primary education program in Islamic studies specialization can master the skills of Tajweed and recitation of Holy Qur'an. The researchers followed the descriptive analytical approach, using: observation card; that was applied to a sample of (22) student teachers at the College of Education, University of Bisha, and a questionnaire was applied to a sample of (35) student teachers. The method of content analysis for the courses of Tajweed and recitation in the program reached (5) courses. The most important results of the research: Student teachers were able in Tajweed and recitation, in light of the objectives of the program's courses, in most of the observation results with an arithmetic mean indicated mastery with an average score of (2.8), a few with an average of (1.8), and very few with an average (1.2). The value of the arithmetic mean for the total observations reached (2.0), that is, the performance was to a small degree according to Likart scale with a standard deviation (0.98). While most of the student teachers' mastery results, from their point of view, indicate that they have an average score of (2.6), a very large with an average (4.0), and that the value of the arithmetic mean is (3.5), that is the performance is highly according to Likart scale, On the availability of Tajweed and recitation skills in the program; the lack of repetitions in some skills were observed, and their increase in others. This confirms the importance of conducting this research and suggesting an enriching list of Tajweed skills, to develop them among student teachers, and to integrate technology in teaching those skills to help master them.
\end{abstract}

Keywords: Evaluation, Tajweed and Recitation Skills, Primary Education Program, College of Education, University of Bisha.

$$
\begin{aligned}
& \text { تقويم مهارات التَّجويد وتلاوة القرآن الكريم ببرنامج التعليم الابتدائي } \\
& \text { في تخصص الدِّراسـات الإسـاميَّة بكليَّة التربية في جامعة بيشـة } \\
& \text { عثمان محمد حامد العالم } \\
& \text { محمد يوسف أحمد السنوسي } \\
& \text { جامعةة بيشـة || المملكة العربية السعودية }
\end{aligned}
$$

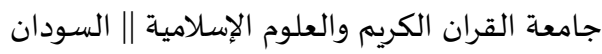

الملخص: هدف البحث إلى التعرف على درجة تمكن الطلاب المعلمين ببرنامج التعليم الابتدائي في تخصص الدراسات الإسلامية من مهارات التجويد وتلاوة القرآن الكريم، وقد اتبع الباحثان المنهج الوصفي التحليلي. باستخدام بطاقة ملاحظة؛ طبقت على دئى عينة بلغت 
(22) طالباً معلماً بكليَّة التربية جامعة بيشة، واستبانة طبقت على عينة بلغت (35) طالباً معلماً، وأسلوب تحليل المحتوى لمقررات

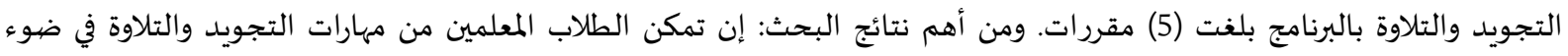

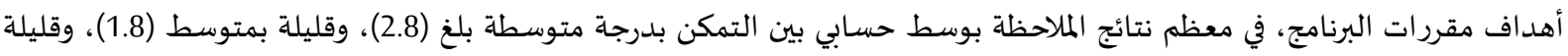

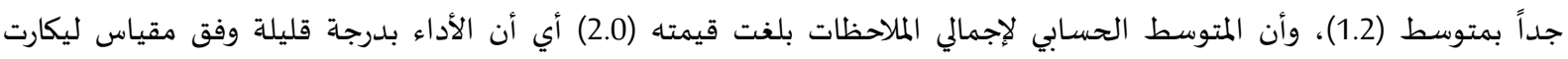

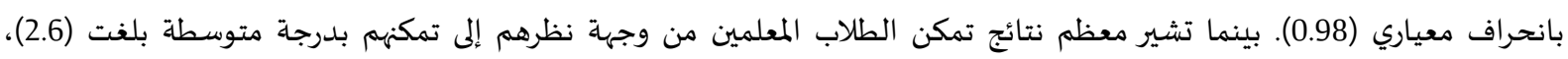

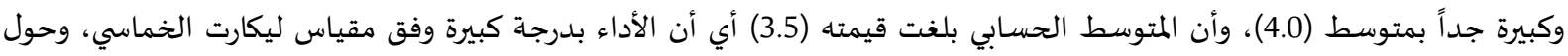

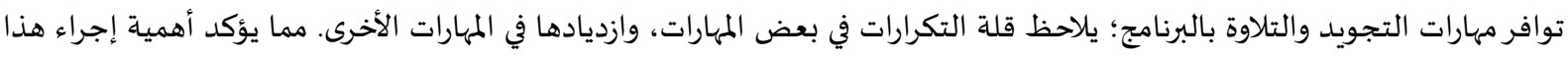

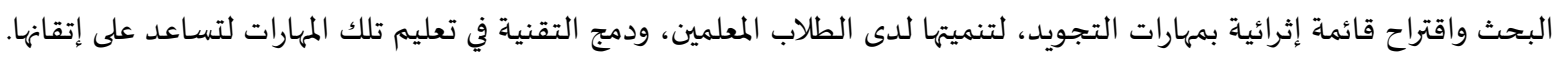

الكلمات المفتاحية: تقويم، مهارات التجويد والتلاوة، برنامج التعليم الابتدائي، كلية التربية، جامعة بيشة.

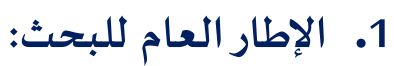

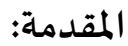

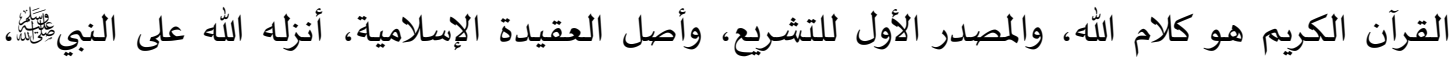

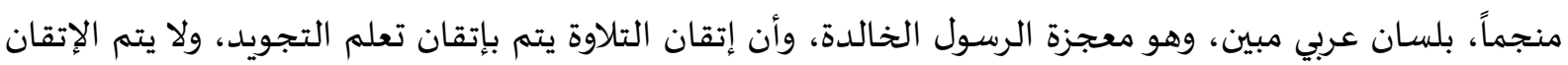

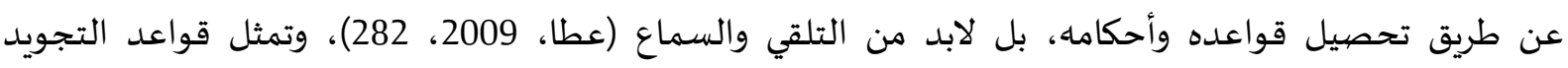

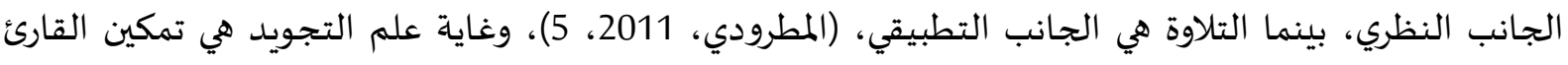

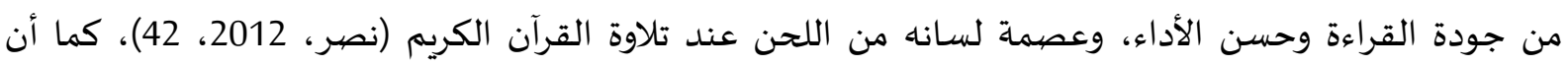

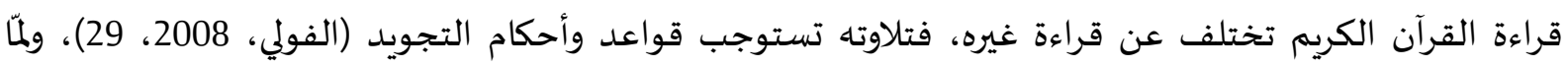

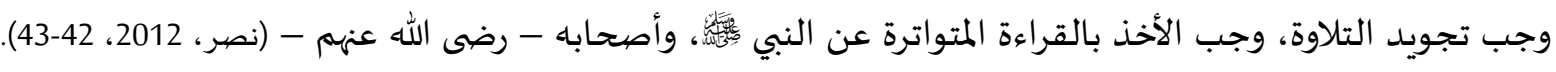

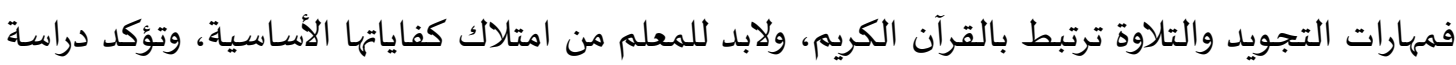

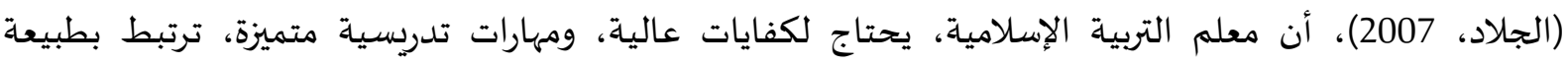

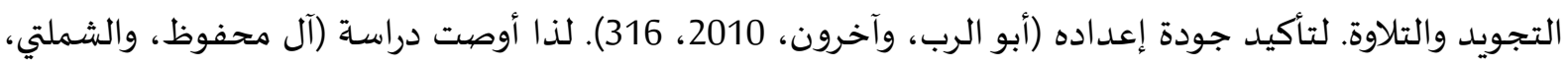

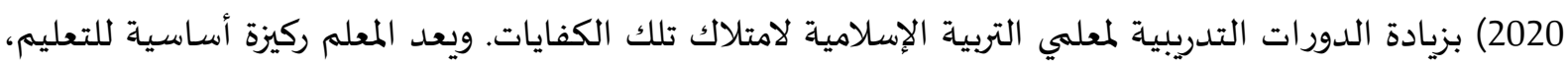

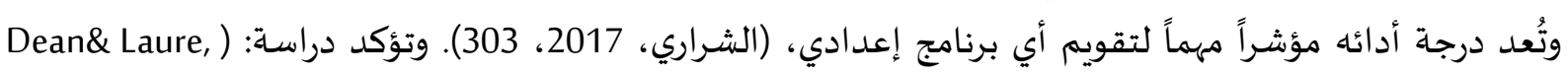

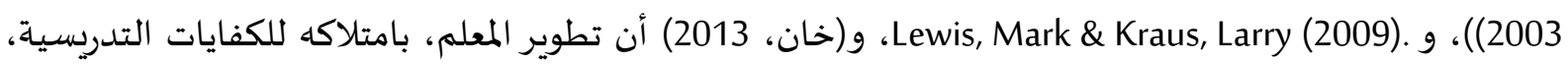
من أهم أهداف برنامج الإصلاح التربوي على المستوى العالمي.

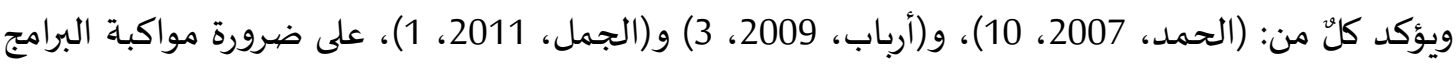
المتعلقة بتعليم التجويد والتلاوة للأبحاث الحديثة في مجال الدراسات اللسانية التعليمية، والمضي في التابل الأخذ بنتائج

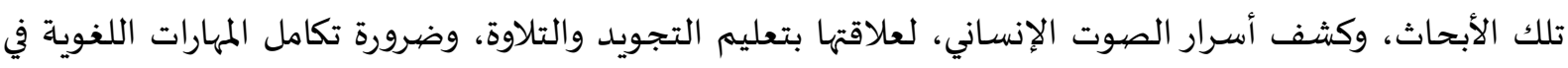
تعلم تلك المهارات.

فبرنامج التعليم الابتدائي يعمل على إعداد معلم الدراسات الإسلامية، وتشكِلِ مقررات التخصص (40\%)

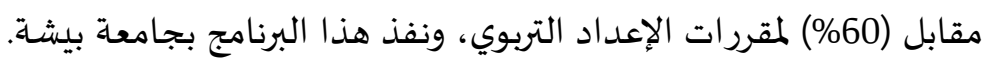

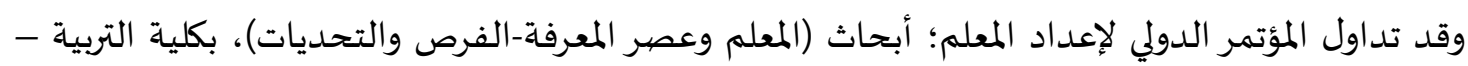

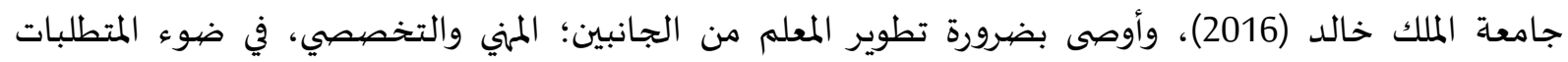

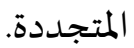


لاحظ الباحثان أن الساعات المخصصة للإعداد الأكاديمي في مقررات التجويد والتلاوة قليلة، وقد أكدت

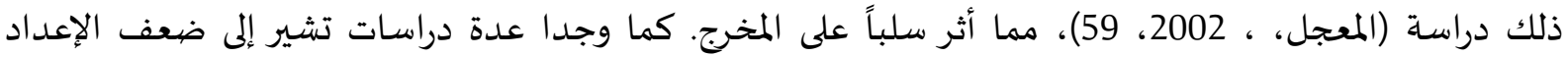

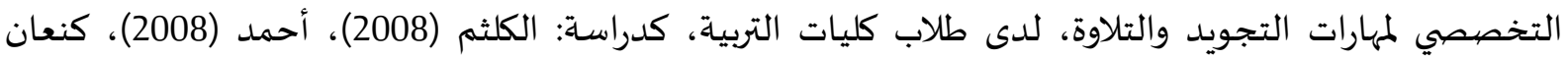

(2009)، الشرعي (2009)، فهد (2010)، السمهر (2011)، الغنبوصي، وآخرون (2012)، خان (2013)، والزعبي

كما لاحظ الباحثان من خلال الإشراف الميداني على الطلاب المعلمين -عينة الدراسة -منذ العام

(1438/1437هـ)، أن هناك قصوراً وضعفاً في أداء الطلاب المعلمين ببرنامج التعليم الابتدائي تخصص المصان الدراسات

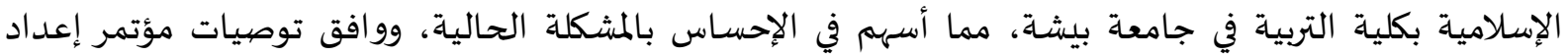

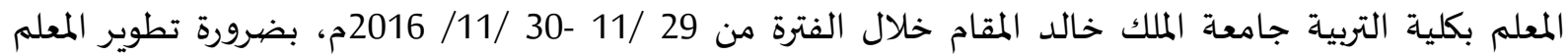
أكاديمياً ومهنياً.

ولما كانت مقررات التجويد والتلاوة أساسية في مقررات الدراسات الإسلامية؛ لإسهامها في تنمية المهارات

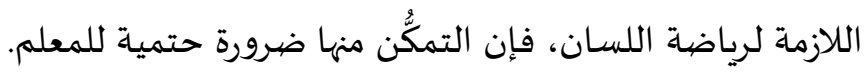
وبناءً على توصيات الدراسات السابقة، وتجربة الباحِثين في الإشراف على الطلاب المعلمين -عينة البحث، ومؤتمر إعداد المعلم بكلية التربية جامعة الملك خالد، -تم تحديد مشكلة البحث في: " وجود قصور يتعلق بغياب

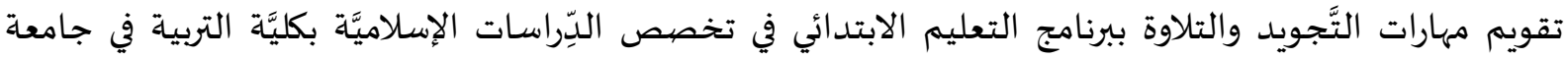

تتمثل مشكلة البحث في الأسئلة الآتية:

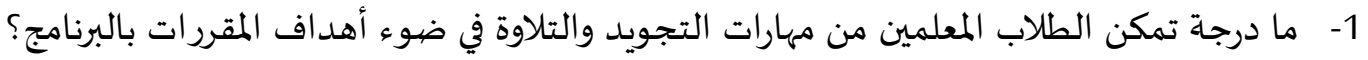

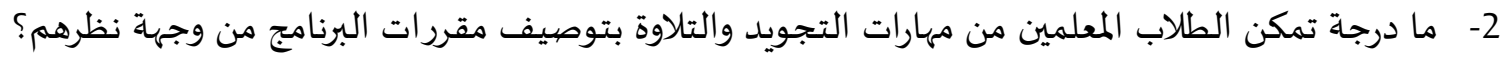

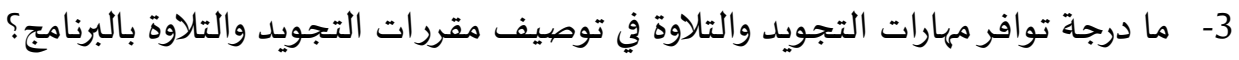

\section{فرضيات البحث:}

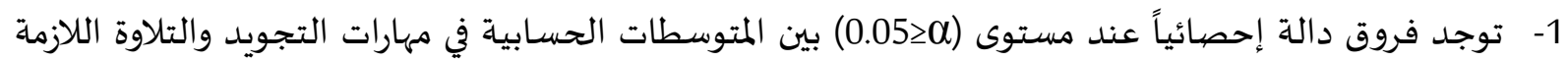
بين طلاب التخصص في توصيف مقررات البرنامج تعزى لضعف تمكنهم من تلك المهارات.

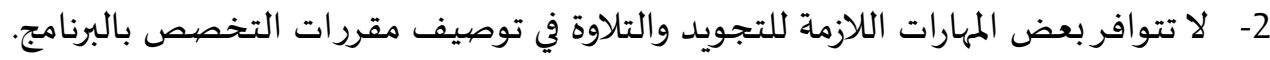

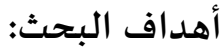

1. التعرُف على درجة تمكن الطلاب المعلمين من مهارات التجويد والتلاوة في ضوء أهداف المقررات بالبرنامج.

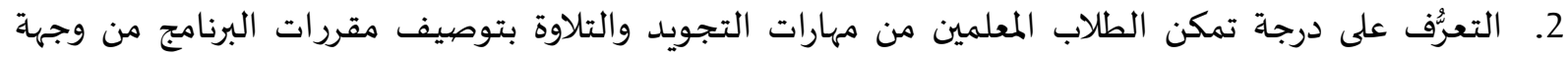
نظرهم. 3. تحديد درجة توافر مهارات التجويد والتلاوة في توصيف مقررات التجويد والتلاوة بالبرنامج. 


$$
\begin{aligned}
& \text { أهمية البحث: } \\
& \text { تكمن أهمية البحث في الآتي: } \\
& \text { 1. الأهمية النظرية: }
\end{aligned}
$$

- - يوفر البحث للطلاب المعلمين في تخصص الدراسات الإسلامية قائمة بمهارات التجويد والتلاوة. - - يقدم إثراءً للإطار النظري المعرفي والتربوي لمهارات التجويد والتلاوة.

- يساعد البحث في سد حاجة قائمة في تحديد مهارات التجويد والتلاوة في مجال التخصص.

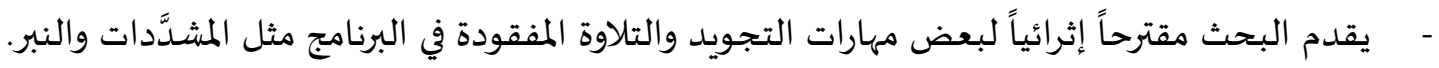

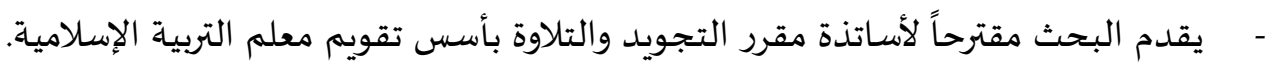

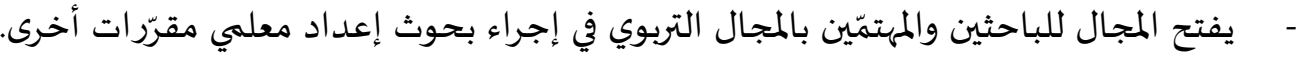

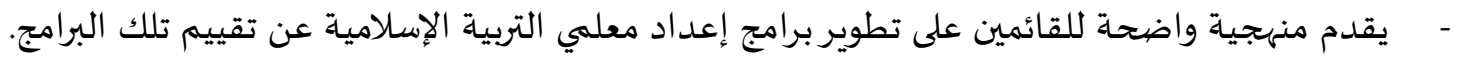

$$
\begin{aligned}
& \text { حدود البحث: } \\
& \text { الحدود الموضوعية: مهارات التجويد والتلاوة بمقررات برنامج التعليم الابتدائي. } \\
& \text { الحدود البشرية: (طلاب الدراسات الإسلامية) بالبرنامج. }
\end{aligned}
$$

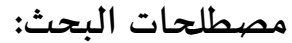

التقويم:

عرفه بلوم بأنه: " إصدار حكم لغرض ما على قيمة الأفكار، الأعمال، الطرائق، ويتضمن استخدام المحكَّات

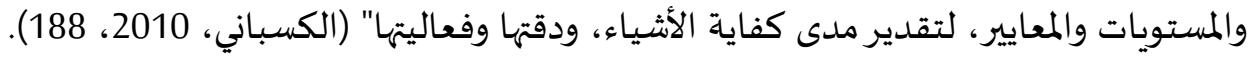

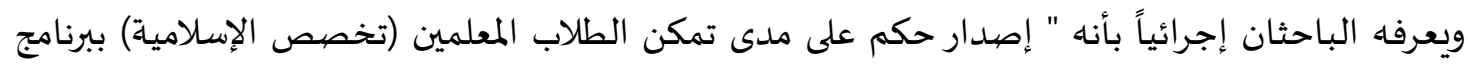
التعليم الابتدائي، من مهارات التجويد والتلاوة".

مهارات التجويد والتلاوة: هي " قدرة الطالب على أداء القرآن الكريم أداءً سليماً، وإخراج الحروف من مخارجها وإعطائها حقها ومستحقها، ومراعاة الوقف والوصل"، (العاصه، 2000، 5. 5).

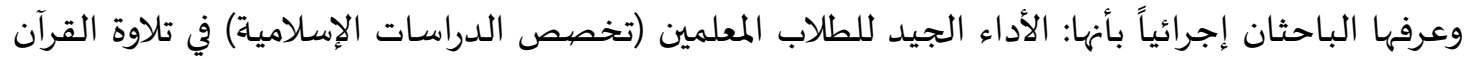
الكريم مع مراعاة تطبيق القواعد والأحكام التجويدية.

برنامج التعليم الابتدائي بكلية التربية في جامعة بيشة:

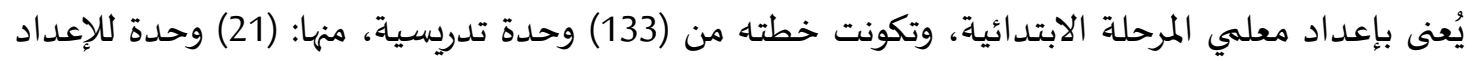

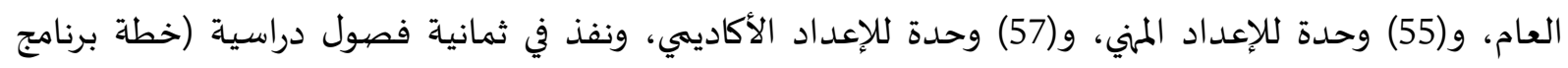

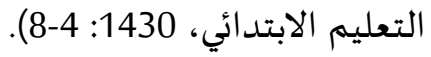


وبعرفه الباحثان إجرائياً بأنه " برنامج لإعداد معلمي الدراسات الإسلامية وأحد التخصصات المعنية في

$$
\text { 2. - الإطار النظري والدراسات السابقة. }
$$

تصنيف مهارات التجويد والتلاوة وأركانها:

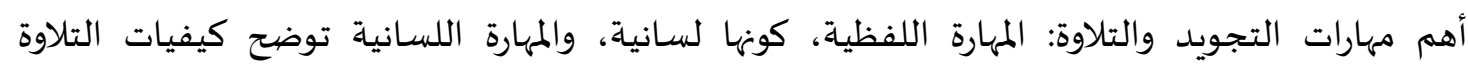

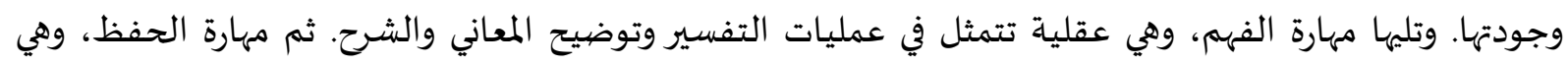

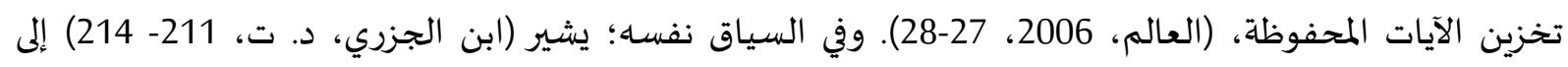

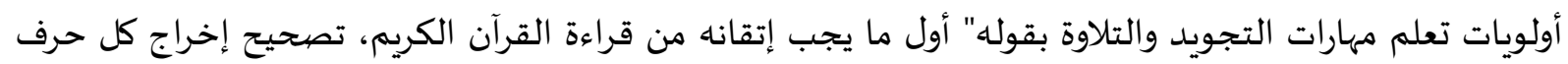

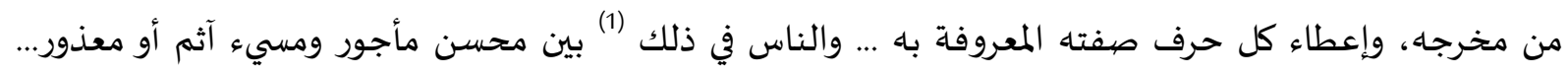

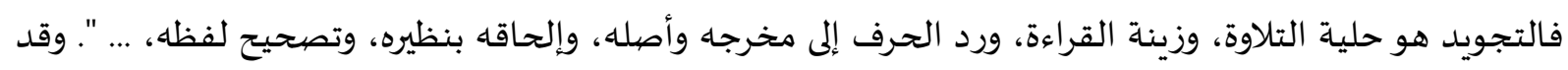
سعى الباحثان للتحقق من تلك المهارات لدى الطابلاب الماب المعلمين.

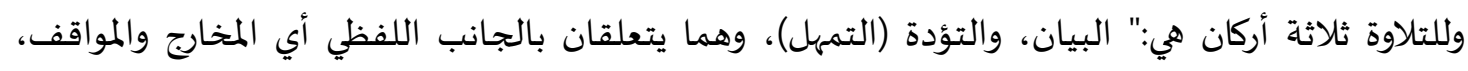

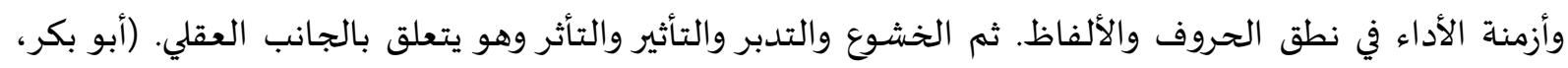
(19-18، 1994

$$
\text { أسـاليب تعليم مهارات التجويد والتلاوة: }
$$

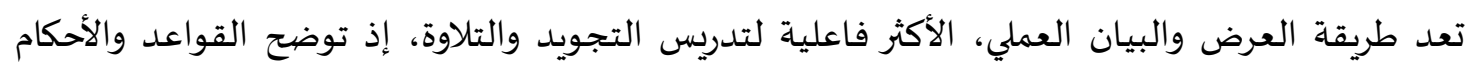

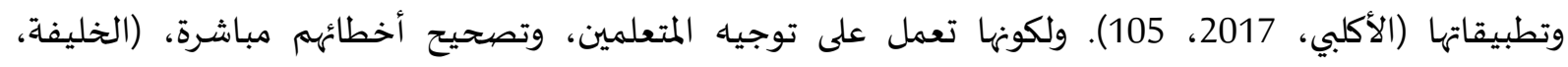

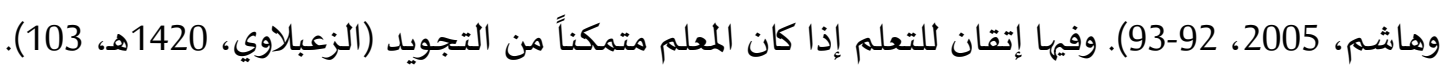

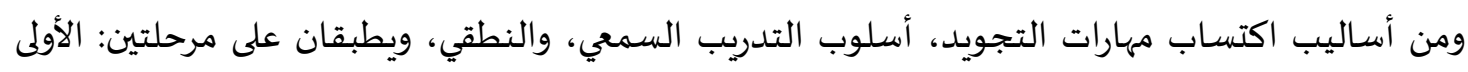

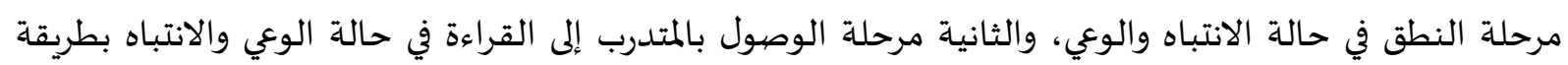

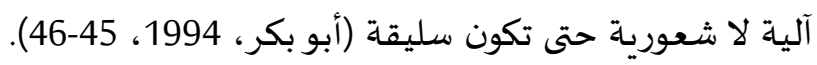

$$
\text { • معلم الدراسات الإسلامية صفاته، وإعداده، وتقويمه: }
$$

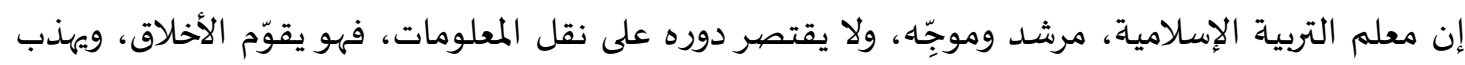

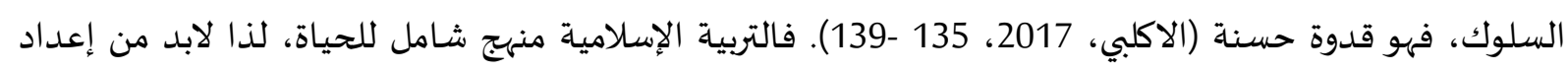

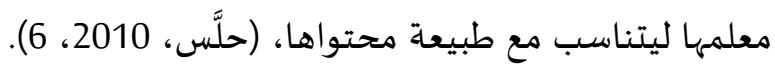

$$
\begin{aligned}
& \text { إعداده: }
\end{aligned}
$$

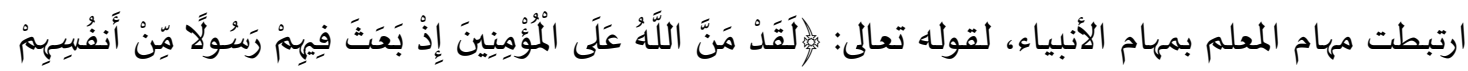

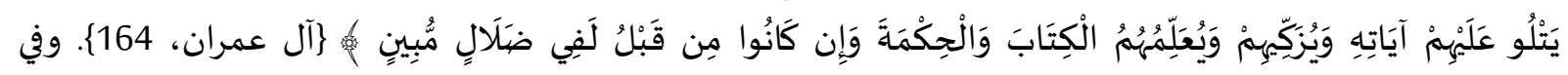

(1) - مقصد أداء مهارات التجويد والتلاوة. 
الحديث: (خَيْرُكُمْ مَنْ تعَلَّمَ القُرَآنَ وَعَلَّمَهُ)، (البخاري، 5027/6). ويرى الباحثان أن الإعداد التتابعي أكثر فاعليةً

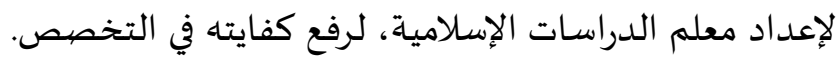
تقويمها:

يُقوَّم معلم الدراسات الإسلامية، بمدى فاعليته بمراحل التدريس الثلاث: التخطيط، التنفيذ، والتقويم.

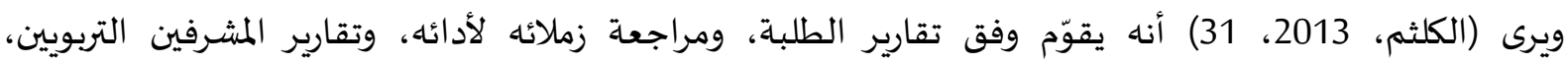

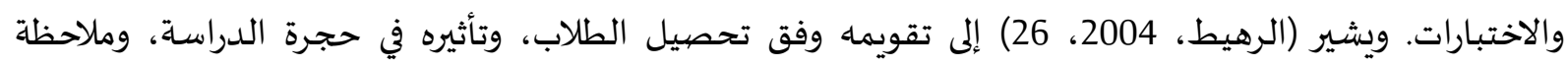

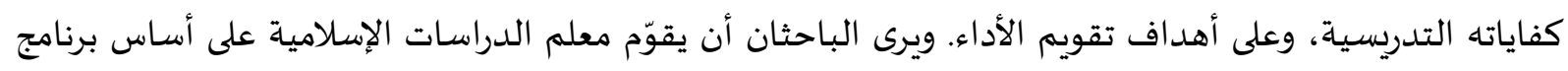
إعداده، لقياس درجة تنميته أكاديمياً ومهنياً.

ثانياً- الدراسات السابقة:

تم إجراء دراسات عدة عن مهارات التجويد والتلاوة، تناولها الباحثان حسب: هدف البحث، المنهج، العيّنة،

الأداة، وأبرز النتائج، التوصيات، والمقترحات. كما في في الآتي:

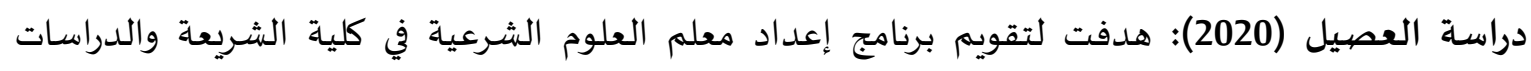

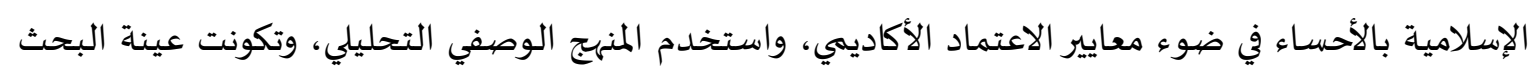

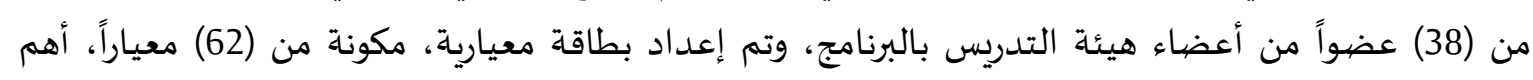

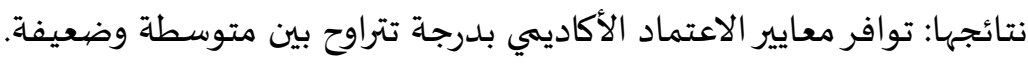

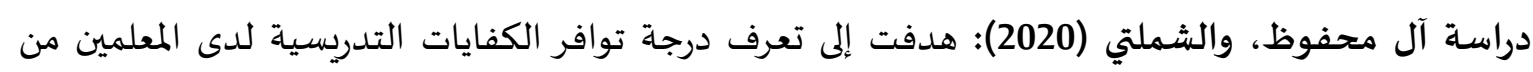

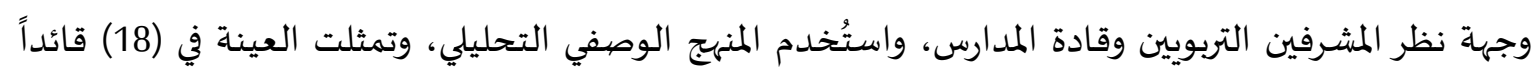

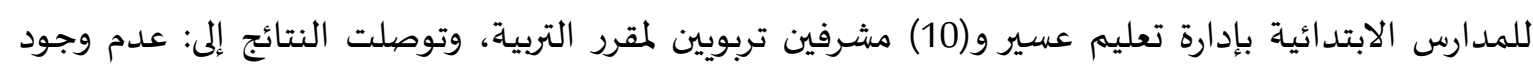

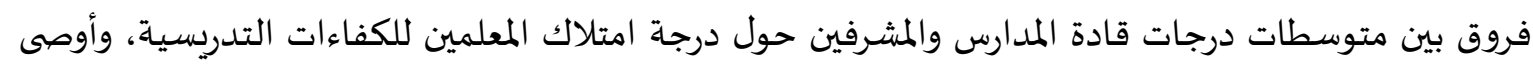
البحث بزيادة الدورات التدريبية للمعلمين للتمكن من الكفايات التدريسية. دراسة الشنقيطي (2019): هدفت إلى تحديد الكفايات اللازمة لتدريس تلاوة القرآن وتجويده، باتدة باتباع المنهنج

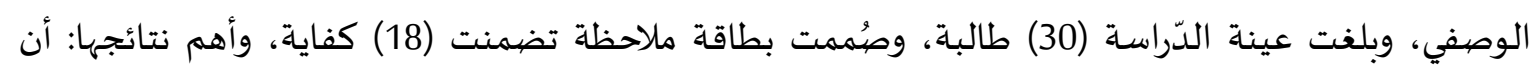
مستوى كفايات تدريس التلاوة والتجويد لدى الطالبات جاء بدرجة متوسطة في أغلب الكفايات عدا كفايتين وصنات جاءتا بدرجة ضعيفة. دراسة العتيبي (2016): هدفت لمعرفة أسباب ضعف مستوى الطلاب في مادة القرآن الكريم، استخدم المنهج

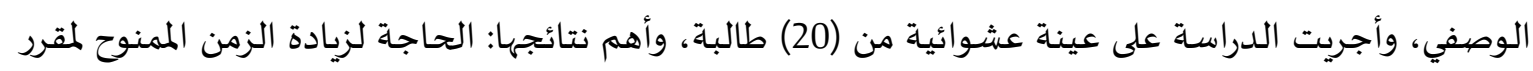

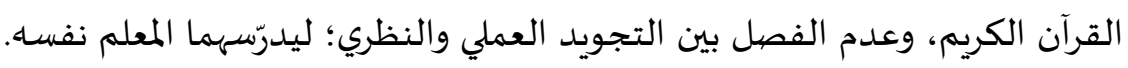

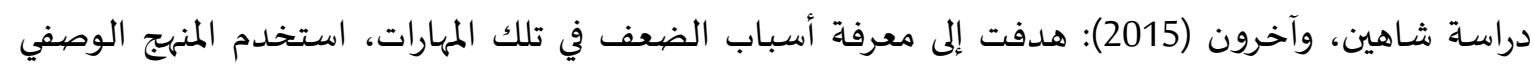

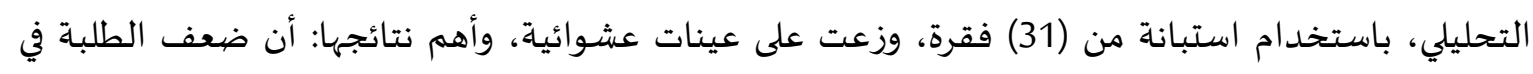

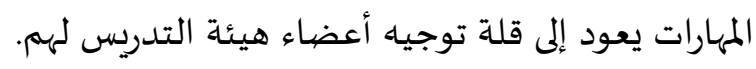
دراسة المطرودي (2013): هدفت لتعرف استخدام بعض الخطوات في فئئ إتقان مهارات التلاوة لدى تلاميذ الصفف

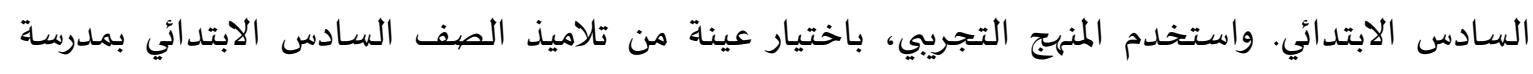

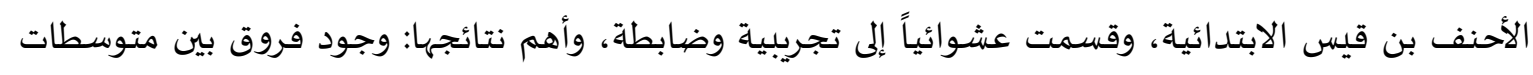

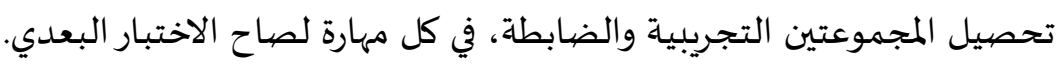


دراسة الزعبي (2013): هدفت لتقويم أداء تلاوة الطلاب لتجويد القرآن الكريم في تربية قصبة المفرق بالأردن، استخدم المنهج الوصفي، وتكونت العينة من (63) طالباً، وأهم نتائجها: أن نسبة أداء الطلاب في مؤشر "يفر لئن

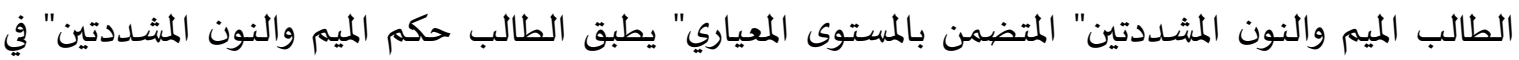
المستوى المرتفع كان منخفضاً جداً، وعدم الأخذ بمبدأ التدرج في تعليم أحكام الميم والنون المعاري.

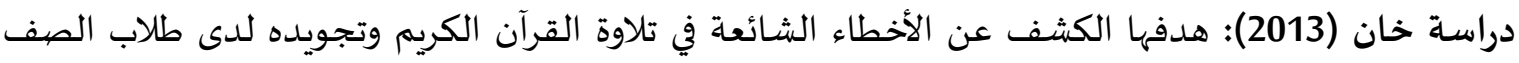

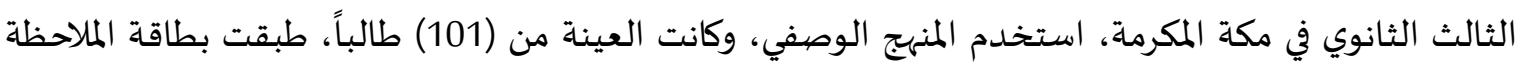

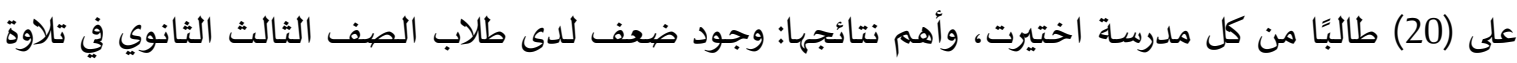
القرآن الكريم. دراسة الغنبوصي، وآخرون (2012): هدفت لتقويم برنامج إعداد المعلم بكلية التربية في جامعة السلطان

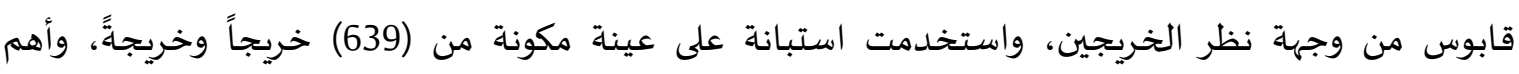

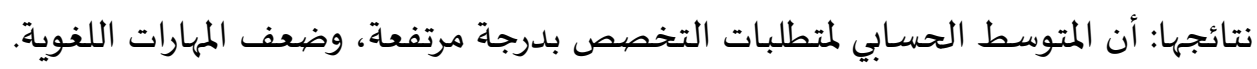

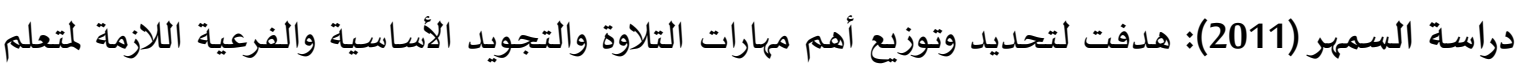

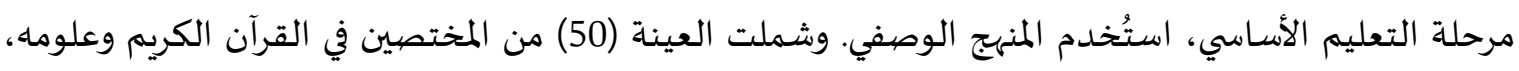

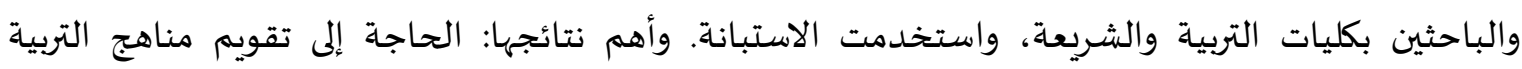
الإسلامية وخاصية مهارات التلاوة والتجويد المقررة.

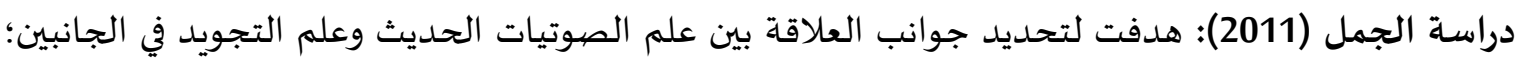

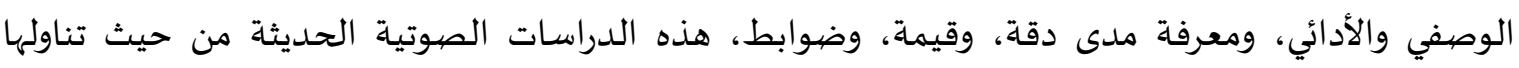

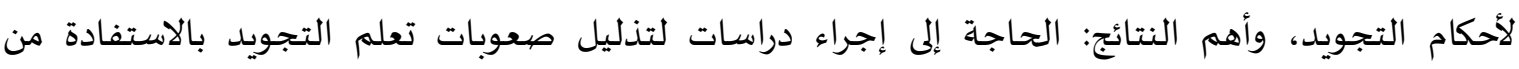
معطيات علم الصوتيات الحديث. دراسة الكلثم (2008): هدفت لتقويم أداء معلم التربية لإسلامية في المرحلة المتوسطة في ضوء نموذج أبعاد

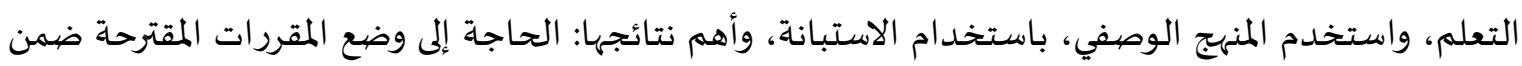
برنامج إعداد معلم التربية الإسلامية في كليات التربية بالسعودياة. دراسة الجلاد (2007): هدفت لتعرف درجة ممارسة مدرسي الدراسات الإسلامية لمهارات تدريس التلاوة

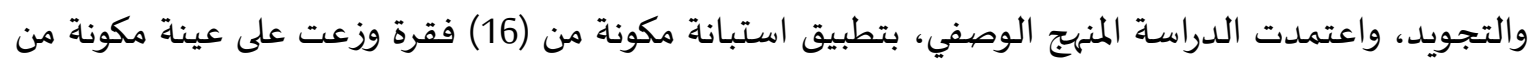

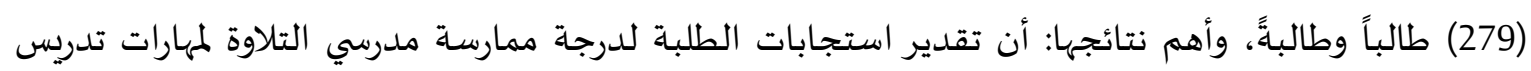

التلاوة والتجويد على مجالات الدراسة مجتمعة بتقدير متوسط.

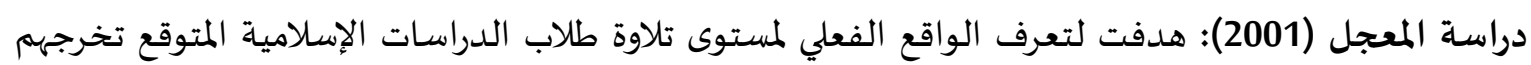

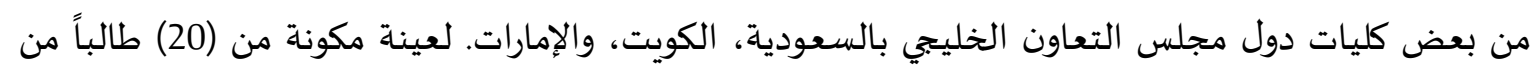

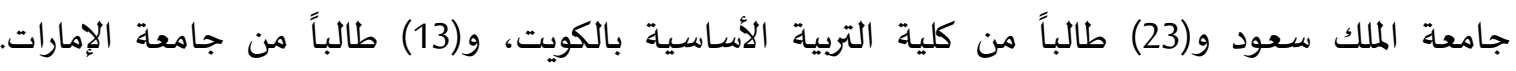

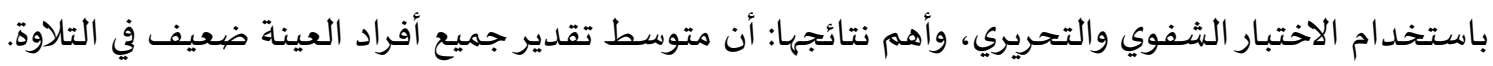

\section{موقع البحث الحالي من الدراسات السابقة:}

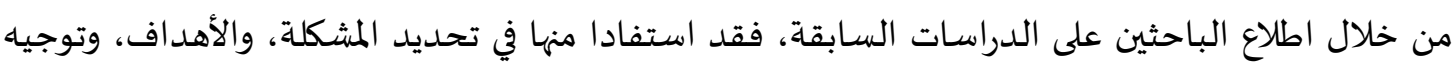
الفرضيات، وإثراء الإطار النظري للبحث، ومن النتائج والتوصيات والمقترحات في تشخيص مواطن الضعف واعنف والقوة

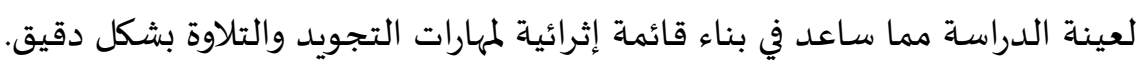


اتفق البحث الحالي مع بعض الدراسات في الأهداف، المنهج، العينة، وبعض الأدوات، كدراساة: الجلاد

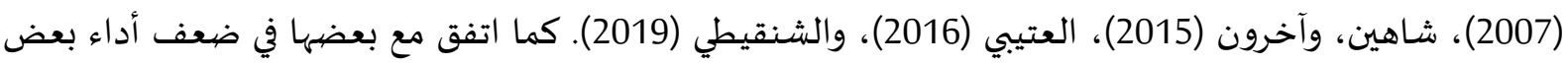
معلمي التربية الإسلامية في مهارات التجويد والتلاوة، كدراسة: المعجل (2002)، الكلثم (2008)، السيمهر (2011)، (2013)،

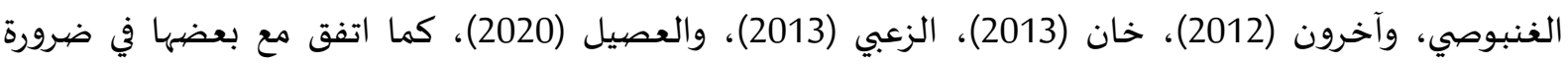

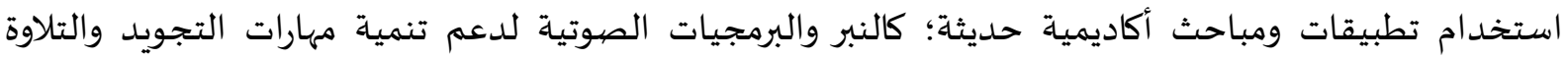

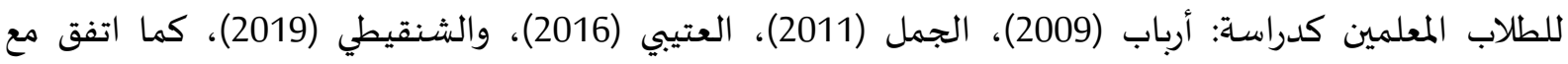
دراسات أشارت إلى أن معلمي الدراسات الإسلامية يتقنون بعض المهابهات المهات، كدراسة أبا نهى (2009)، والمطرودي (2013). واتفق مع أخرى أوصت بضرورة تقويم أداء معلمي القرآن الكريم وكفاياتهم التدريسية اللازمة، كدراسـة: الزعبي (2013)، شاهين، وآخرون (2015)، وآل محفوظ، واخدو والشملتي (2020).

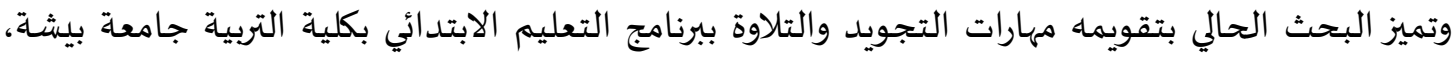
وباستخدامه أسلوب تحليل المحتوى التعليمي لمقررات التجويد والتلاوة بالبرنامج، ووضع قائمة إثرائية بمهارات التجويد والتلاوة لتنميتها لدى عينة الدراسـة.

3. منهجية البحث وإجراءاته.

منهج البحث: استخدم الباحثان المنهج الوصفي التحليلي، بهدف التعرف على مهارات التجويد والتلاوة لدى الطلاب المعلمين بتخصص الدراسات الإسلامية بالبرنامج.

\section{مجتمع البحث وعينته:}

يمثل المجتمع طلاب كلية التربية (تخصص الدراسات الإسلامية) الذين أكملوا ثمانية فصيول دراسية للعام الجامعي 1441/1440هـ، وتمثلت عينة البحث في الآتي:

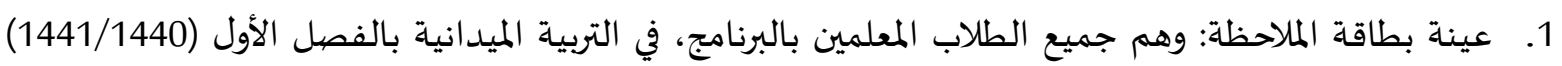
والبالغ عددهم (35) طالباً معلماً، تمت ملاحظة (22) منهم، وتم اختيارهم كعينة قصدية.

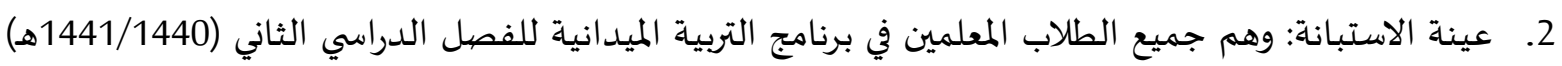

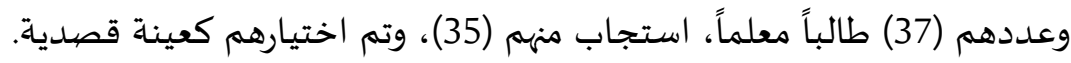

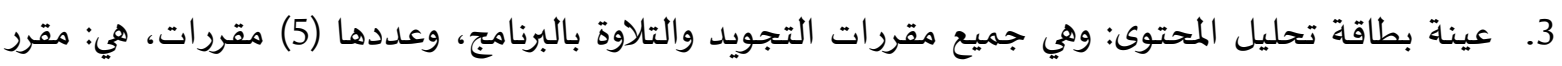

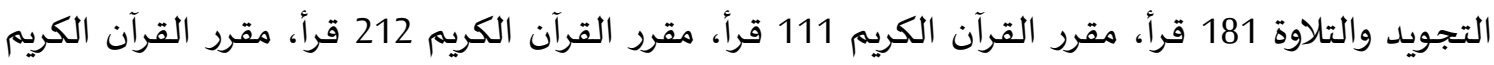
213 قرأ، مقرر القرآن الكريم 314 قرأ.

$$
\text { أدوات البحث: استخدمت مجموعة من الأدوات تمثلت في: }
$$

أولاً - قائمة مهارات التجويد والتلاوة: أ- أعدت من خلانة مهارات الاطجلاع على أدبيات البرنامج وتحليل مقرراته، وحولت لبطاقة تحليل محتوى مقررات

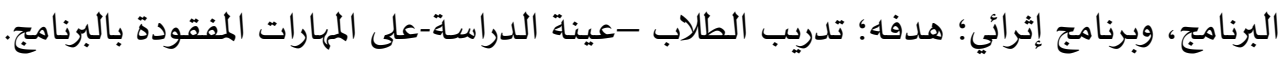


ب- تم عرض القائمة على عدد من المختصين؛ لإبداء آرائهم، وتعليقاتهم، وعُدلت كل ملاحظاتهم بإعادة صياغة بعض المؤشرات، وإضافة بعض المؤشرات، حيث اتفق المحكمون بنسبة (90\%)؛ لتصبح القائمة (54) مهارة من (58) مهارة كما يلي:

جدول (1) قائمة مهارات التجويد والتلاوة

\begin{tabular}{|c|c|c|}
\hline 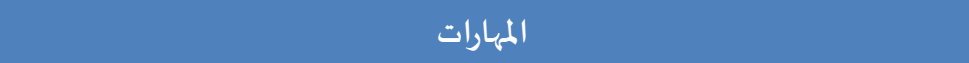 & $\hat{\imath}$ & ق ق قواعد المهارات \\
\hline إخراج الحروف من مخارجها & 1 & \multirow{2}{*}{ 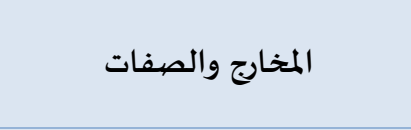 } \\
\hline نطق الحروف بصفاتها المستحقة في الإفراد والتركيب & 2 & \\
\hline حروف " قطب جد " حال سكونها في الكلمة & 3 & 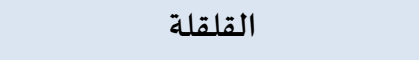 \\
\hline حرف الراء في الكلمة حال سكونها & 4 & \multirow{4}{*}{ 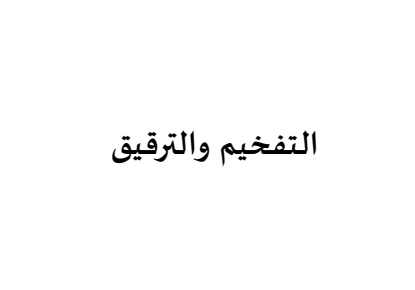 } \\
\hline حرف الراء في الكلمة حال كسرها & 5 & \\
\hline لام لفظ الجلالة بعد فتح أوضهم & 6 & \\
\hline لام لفظ الجلالة بعد كسر أو سكون & 7 & \\
\hline لام أل القمرية (لام التعريف) قبل حروف: (الألف، الباء، الغين، الحاء، الجيم، & 8 & \multirow{2}{*}{ 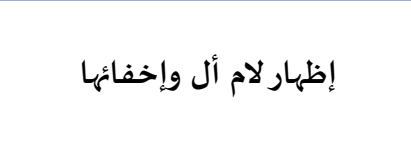 } \\
\hline لام أل الشمسية (لام التعريف) قبل الحروف: (الطاء، الثاء، الصاد، التاء، & 9 & \\
\hline لام الفعل الساكنة في مواضعها المختلفة بالكلمة & 10 & 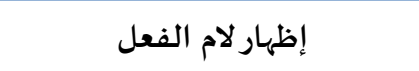 \\
\hline النون الساكنة والتنوين عند ملاقاة الحروف: (الهمزة، الهاء، العين، الحاء، & 11 & \multirow{6}{*}{ أحكام النون الساكنة والتنوين } \\
\hline النون الساكنة في حرفي الواو والياء في كلمة واحدة مطلقا (الدنيا، بنيان، & 12 & \\
\hline النون الساكنة والتنوين بغنة عند ملاقاة الحروف: (الياء، النون، الميم، الواو) & 13 & \\
\hline النون الساكنة والتنوين بغير غنة عند التقاء حرفي اللام والراء & 14 & \\
\hline النون الساكنة والتنوين عند ملاقاة الحروف: (الصهاد، الذال، الثاء، الكاف، & 15 & \\
\hline النون الساكنة والتنوين عند ملاقاة حرف الباء & 16 & \\
\hline 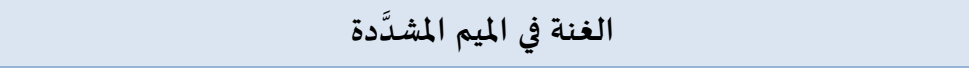 & 17 & \multirow{2}{*}{ 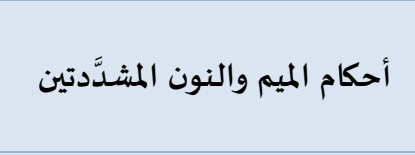 } \\
\hline 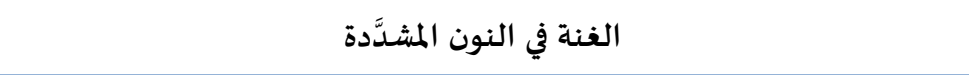 & 18 & \\
\hline الميم الساكنة عند التقائها بحرف الباء & 19 & \multirow{3}{*}{ 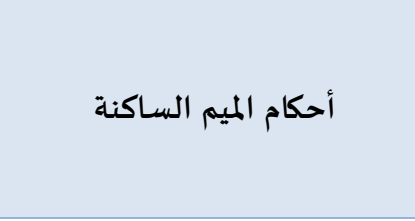 } \\
\hline الميم الساكنة عند التقائها بحرف الميم & 20 & \\
\hline الميم الساكنة عند التقائها بجميع حروف الهجاء عدا الباء والميم & 21 & \\
\hline إدغام الحرفين المتماثلين تماثلاً صغيراً & 22 & \multirow{6}{*}{ 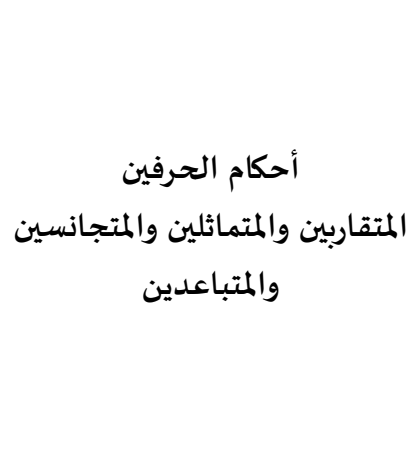 } \\
\hline إظهار الحرفين المتماثلين تماثلاً كبيراً أو مطلقاً & 23 & \\
\hline 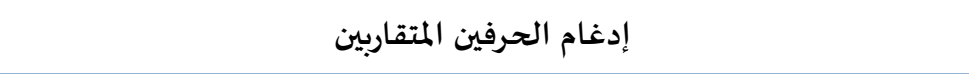 & 24 & \\
\hline إدغام لحرفين المتجانسين & 25 & \\
\hline إظهار الحرفين المتباعدين تباعداً صغيراً مطلقاً & 26 & \\
\hline إظهار الحرفين المتباعدين تباعداً كبيراً مطلقاً & 27 & \\
\hline
\end{tabular}


المجلة العربية للطوم ونثر الأبحاث ـ مجلة العلوم التريوية والنفسية ـ المجلد الخامس ـ العدد الثاني ـ يناير 2021م

\begin{tabular}{|c|c|c|}
\hline 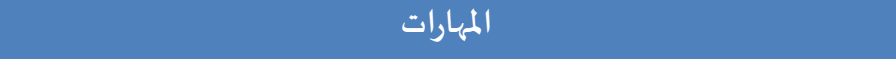 & $\hat{c}$ & 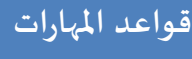 \\
\hline إخفاء الحرفين المتباعدين تباعدا صغيرا في القاف والكاف & 28 & \\
\hline حروف المد الطبيعي بمقدار حركتين & 29 & \multirow{7}{*}{ 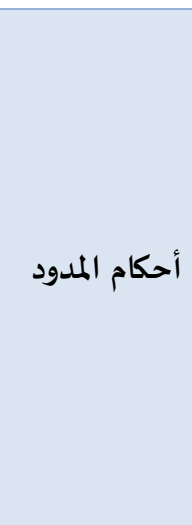 } \\
\hline المد المتصبل بمقدار أربع حركات أوخمس أو ست & 30 & \\
\hline المد المنفصل بمقدار أربع حركات أو خمس & 31 & \\
\hline مد الصلة الصغرى بمقدار حركتين & 32 & \\
\hline مد الصلة الصغرى نطقاً سليماً & 33 & \\
\hline المد اللازم بمقدار ست حركات مع استثناء بعض مواضعه & 34 & \\
\hline المد العارض للسكون قصراً (حركتين)أو توسطاً (أربعاً) أو إشباعاً (ستاً). & 35 & \\
\hline مواضع الحركات والسكنات في التلاوة نطقاً سليماً & 36 & 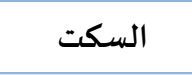 \\
\hline 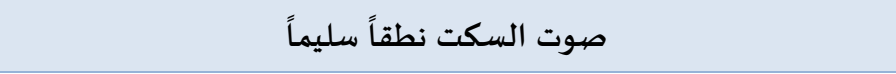 & 37 & \\
\hline النطق بإسقاط الهمزة حال الوصل & 38 & \multirow{2}{*}{ 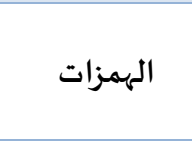 } \\
\hline النطق بإسقاط همزة الوصل حال الابتداء & 39 & \\
\hline نطق مواضع الوقف على الكلمة نطقاً سليماً & 40 & \multirow{9}{*}{ والوالرست } \\
\hline الوقوف على حروف العلة وقوفاً سليماً & 41 & \\
\hline مواضع الوقف على التاء نطقا سليماً & 42 & \\
\hline مواضيع الوقف على الهاء نطقاً سليماً & 43 & \\
\hline مواضع الوقف الاختياري عند التلاوة & 44 & \\
\hline مواضع الوقف الجائز عند التلاوة & 45 & \\
\hline مواضيع الوقف القبيح & 46 & \\
\hline علامات الوقف واصطلاحات الرسم بالمصاحف عند التلاوة & 47 & \\
\hline مواضع الابتداء نطقاً سليماً & 48 & \\
\hline قاعدة الروم في مواضعه لدى التلاوة & 49 & \multirow{2}{*}{ والإشمام } \\
\hline قاعدة الإشمام في مواضعه لدى التلاوة & 50 & \\
\hline نطق المشـدَّد المفرد & 51 & \multirow{3}{*}{ 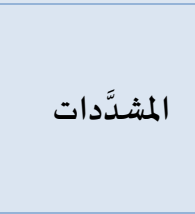 } \\
\hline نطق المشددّد الذي اجتمع فيه حرفان مشدَّدان & 52 & \\
\hline نطق المشَّددد الذي اجتمع فيه ثلاثة مشـدَدات متواليات بدقة & 53 & \\
\hline تعرُّف أخطاء التلاوة حسب ورودها بدقة & 54 & أخطاء التلاوة \\
\hline
\end{tabular}

ثانياً: أداة الملاحظة: أ- صدق أداة الملاحظة: تم إعداد بطاقة الملاحظة في صورتها الأولية من (24) مهارة للتجويد والتلاوة، وللتحقق من صدق الأداة عرضت على (6) من المختصين في الدراسات الإسلامية، والمناهج وطرق التدريس، للتأكد من تناسبها مع أهداف البحث، وملائمة كل مهارة لقاعدتها، وتمت مراعاة ملاحظاتهم من حيث الحذف ادف والإضيافة والتعديل، 
لتصبح (25) مهارة في خمسة محاور. ولصدق الاتساق الداخلي لأداة الملاحظة تم حساب صدق الاتساق الداخلي كما يلي: جدول (2) يوضح نتائج الاتساق الداخلي:

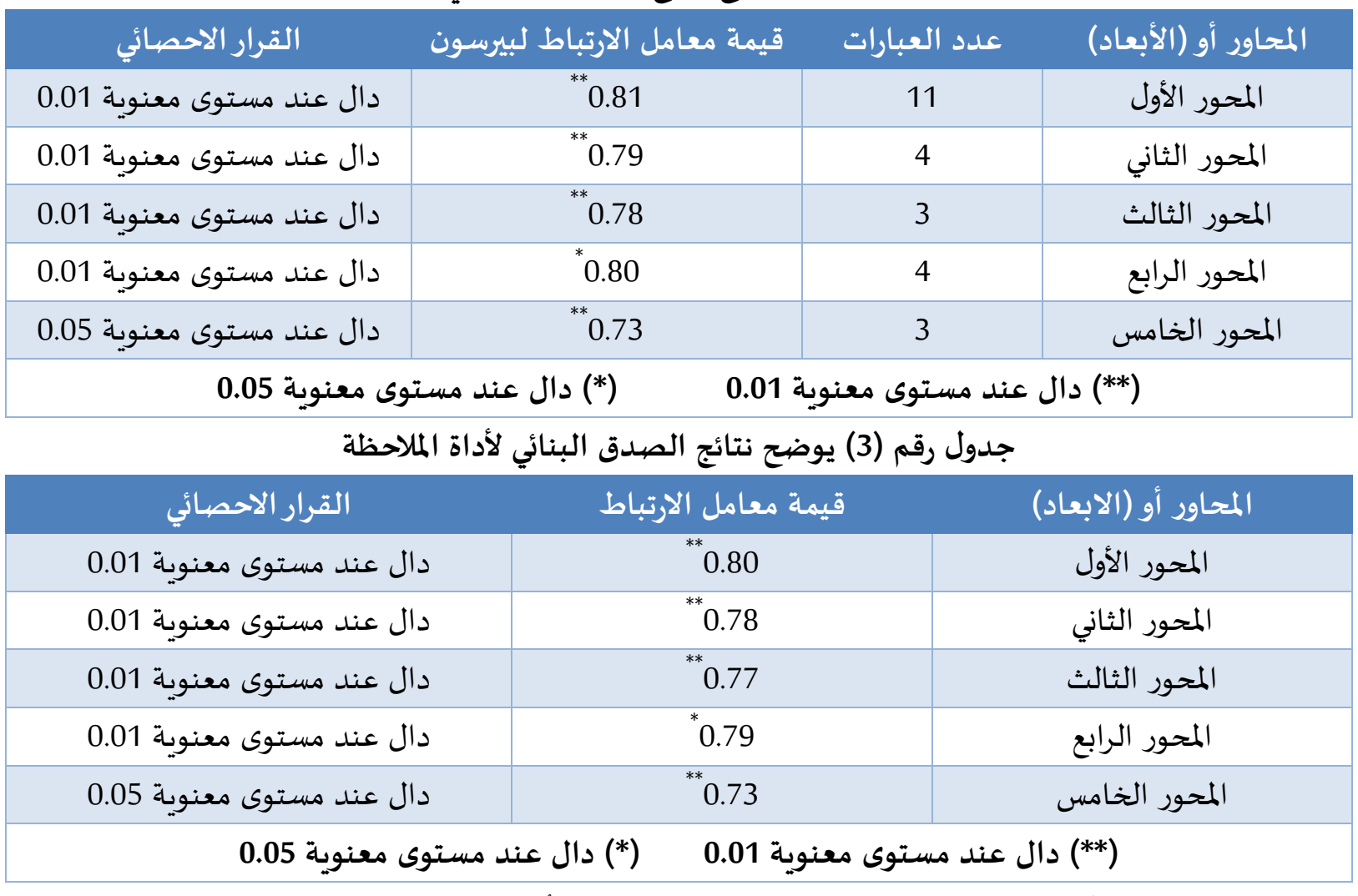

يوضح جدول (3) نتائج الصدق لمحاور بطاقة الملاحظة لأداء الطلاب المعلمين-عينة البحث-في مهارات

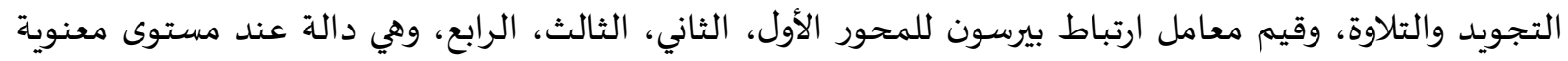

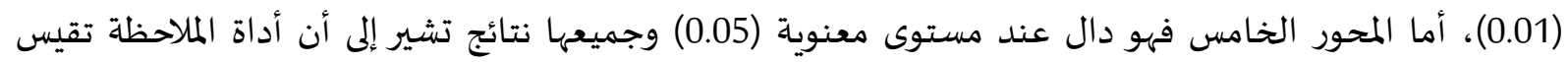
الأهداف التي صممت لقياسها. ب- ب ثبات أداة الملاحظة: الجدول رقم (4) يوضح قيمة معامل ألفا كرونباخ

\begin{tabular}{|c|c|c|}
\hline معامل الفا كرونباخ & عدد العبارات & المحاور أو (الأبعاد) \\
\hline 0.80 & 11 & المحور الأول \\
\hline 0.78 & 4 & المحور الثاني \\
\hline 0.77 & 3 & المحور الثالث \\
\hline 0.78 & 4 & المحور الرابع \\
\hline 0.72 & 3 & المحور الخامس \\
\hline 0.79 & 25 & إجمالي المحاور \\
\hline
\end{tabular}

جدول (4) يوضح قيم معاملات ألفا كرونباخ لقياس الثبات لأداة الملاحظة، وجميع القيم مرتفعة ومقبولة إحصائياً، وقيمة معامل ألفا كرونباخ لإجمالي عدد عبارات الأداة (0.79). 
ثالثاً: استبانة التعرف على مهارات التجويد والتلاوة في ضهوء أهداف المقررات:

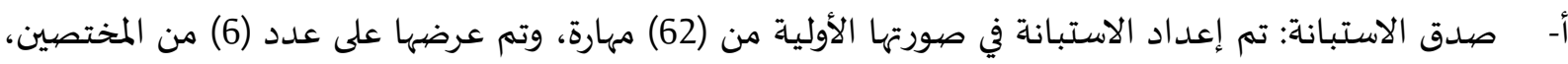

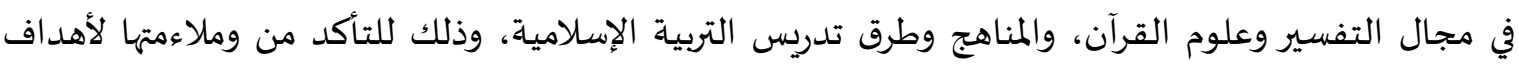

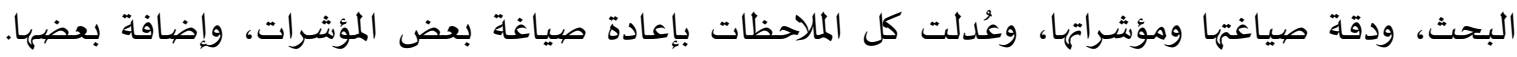

لتصبح (64) مهارة في خمسة محاور، بصورتها ونها النهائية.

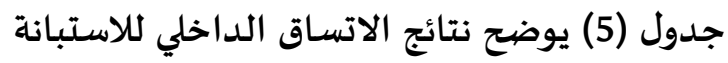

\begin{tabular}{|c|c|c|}
\hline قيمة معامل الارتباط لبيرسون & عدد العبارات & المحاور أو (الابعاد) \\
\hline *** 0.80 & 28 & المحور الأول \\
\hline${ }^{* *} 0.77$ & 8 & المحور الثاني \\
\hline${ }^{* *} 0.82$ & 15 & المحور الثالث \\
\hline * 0.73 & 4 & المحور الرابع \\
\hline${ }^{* *} 0.79$ & 9 & المحور الخامس \\
\hline
\end{tabular}

جدول (5) نتائج الصدق لمحاور بطاقة ملاحظة أداء الطلاب المعلمين في مهارات التجويد والتلاوة -عينة

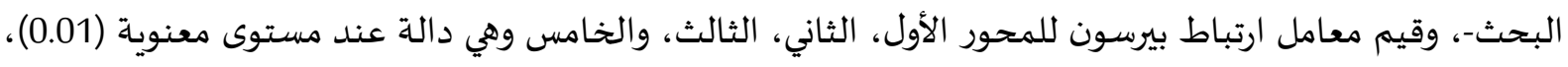

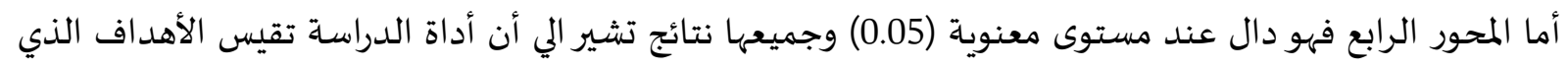

الجدول رقم (6) يوضح قيمة معامل الفا كرونباخ

\begin{tabular}{|c|c|c|}
\hline معامل ألفا كرونباخ & عدد العبارات & المحاور أو (الأبعاد) \\
\hline 0.80 & 28 & المحور الأول \\
\hline 0.76 & 8 & المحور الثاني \\
\hline 0.85 & 15 & المحور الثالث \\
\hline 0.73 & 4 & المحور الرابع \\
\hline 0.79 & 9 & المحور الخامس \\
\hline 0.79 & 64 & إجمالي المحاور \\
\hline
\end{tabular}

جدول (6) يوضح قيم معاملات ألفا كرونباخ لقياس ثبات الاستبانة، وجميع القيم مرتفعة ومقبولة إحصائياً وقيمة معامل ألفا كرونباخ لإجمالي عدد عبارات الاستبانة (0.79).

رابعاً: بطاقة تحليل المحتوى: وتمثلت خطواتها في التالي:

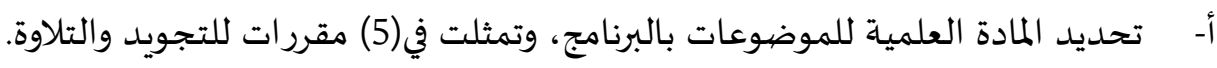

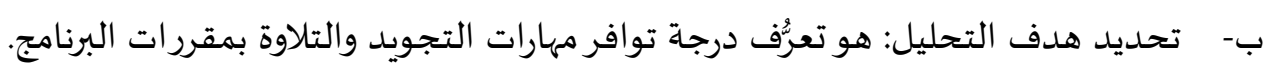

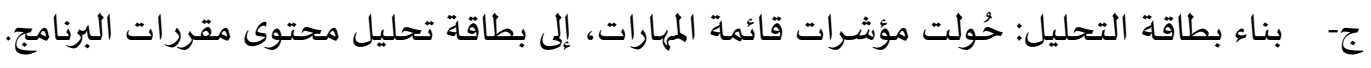

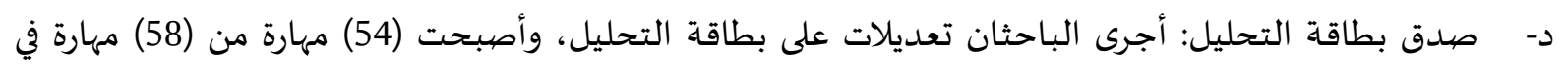
صورتها الأولية، 
وللتأكد من ثبات بطاقة التحليل، طُبق حساب نسبة الاتفاق بين الباحثين؛ -أي المحللين للمحتوى التعليمي

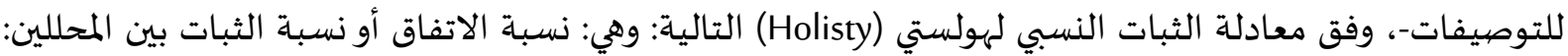
ر= [2م/ ن1+ ن2] (طعيمة، 1999: 178)، وبلغت نسبة الاتفاق حول مؤشراتها، ما نسبته (95\%) وهي نسبة عادية عالية، وصالحة للاعتماد عليها في التحليل. - الأساليب الإحصائية: تمت معالجة بيانات البحث باستخدام برنامج الرزم الإحصائية للعلوم الاجتماعية

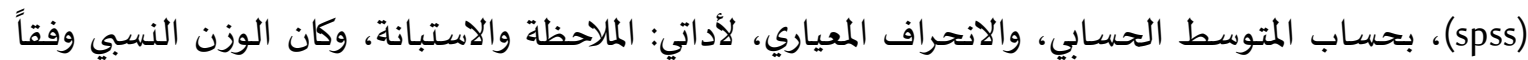
لمقياس ليكارت والمتوسطات ومدياتها والتقديرات للاستبانة كما في الجدول التالي: جدول (7) مفتاح توزيع المتوسطات في مقياس ليكارت الخماسي واسي

\begin{tabular}{|c|c|}
\hline عبارات المقياس & فقرات مقياس ليكارت الخماسي \\
\hline بلدرجة قليلة جدا & $1.80-1$ \\
\hline بدرجة قليلة & $2.60-1.81$ \\
\hline بلدرجة متوسطة & $3.40-2.61$ \\
\hline بلدرجة كبيرة & $4.20-3.41$ \\
\hline بدرجة كبيرة جداً & $5-4.21$ \\
\hline
\end{tabular}

ولصدق وثبات أداتي الملاحظة والاستبانة استخدمت معادلة الصدق (بيرسون)، ومعادلة الثبات (ألفا

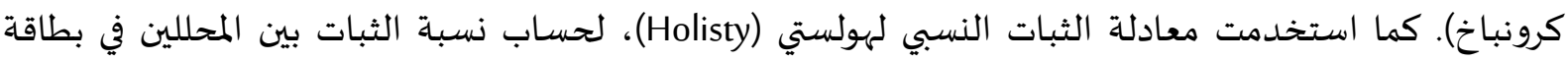
تحليل المحتوى التعليمي لتوصيفات البرنامج، كمون

4. نتائج البحث ومناقشتها وتفسيرها: هالإجابة عن السؤال الأول: "ما درجة تمكن الطلاب المعلمين من مهارات التجويد والتلاوة في ضوء أهداف

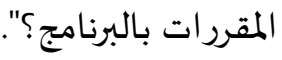

ولإجابة عن السؤال: تم حساب المتوسط الحسابي، والانحراف المعياري، للإحصاءات الوصفية لملاحظة درجة تمكن الطلاب المعلمين من مهارات التجويد والتلاوة. جدول (8) درجة تمكن الطلاب المعلمين بالبرنامج من مهارات التجويد وتلاوة القرآن الكريم في ضوء أهوات أهداف المقررات

\begin{tabular}{|c|c|c|c|c|}
\hline دالمهارة - اداء & 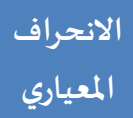 & المتوسط & مؤشرات أداء المهارات & 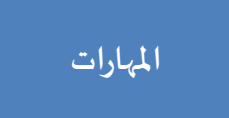 \\
\hline كبيرة & .77 & 3.7 & يستطيع الطالب المعلم نطق كل الحروف العربية & المخارج والصفات \\
\hline كبيرة & .91 & 3.6 & لدى الطالب المعلم معرفة تامّة بحروف القلقلة & \multirow{2}{*}{ 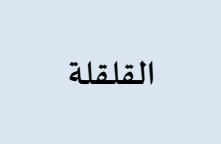 } \\
\hline 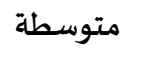 & .96 & 2.8 & يجيد الطالب المعلم نطق حروف القلقلة في كل حالاهها & \\
\hline قليلة & 1.3 & 2.3 & يجيد الطالب المعلم نطق حروف التفخيم في كل حالاتها & 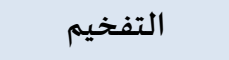 \\
\hline قليلة & 1.2 & 2.2 & يجيد الطالب المعلم نطق حروف الترقيق في كل حالاتها & 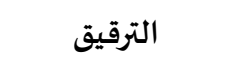 \\
\hline كبيرة & .99 & 2.7 & يتقن الطالب المعلم نطق لام أل في كل حالاتها & 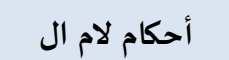 \\
\hline
\end{tabular}




\begin{tabular}{|c|c|c|c|c|}
\hline درجة اداء & الانحراف & المتوسط الحسابي & مؤشرات أداء المهارات & 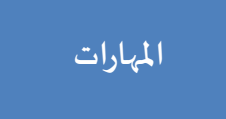 \\
\hline قليلة & .78 & 2.3 & يجيد الطالب المعلم نطق لام الفعل & 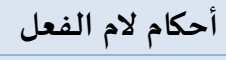 \\
\hline 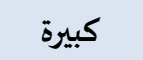 & 1.6 & 2.9 & يجيد الطالب المعلم نطق صفة الغُنَّة & 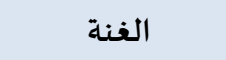 \\
\hline 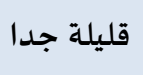 & 1.1 & 1.7 & يجيد الطالب المعلم نطق الحرفين المتقاربين & \multirow{3}{*}{ والحكام الحرفين } \\
\hline متوسطة & .95 & 2.8 & يجيد الطالب المعلم نطق الحرفين المتماثلين & \\
\hline قليلة & 1.3 & 2.4 & يجيد الطالب المعلم نطق الحرفين المتجانسين & \\
\hline متوسطة & 1.6 & 2.7 & لدي الطالب المعلم معرفة كافية بأنواع المدود & \multirow{2}{*}{ 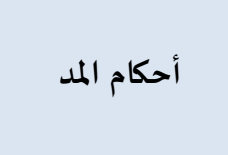 } \\
\hline ق قليلة & 1.2 & 2.3 & يجيد الطالب المعلم نطق المدود بأنواعها & \\
\hline قليلة & 1.4 & 2.5 & يجيد الطالب المعلم نطق مواضع السكت في القرآن & 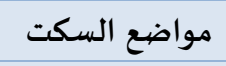 \\
\hline متوسطة & 1.6 & 2.8 & يحسن الطالب المعلم نطق مواضع الوقف في القرآن & 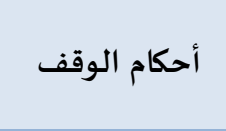 \\
\hline متوسطة & 1.2 & 3.3 & يتعرُّف الطالب المعلم علامات الوقف في القرآن الكريم & \multirow{2}{*}{ علامات الوقف } \\
\hline 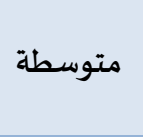 & 1.6 & 2.9 & يتعرُف الطالب المعلم اصطلاحات الرسم في القرآن & \\
\hline ق قليلة & 1.3 & 2.4 & لدى الطالب المعلم معرفة كافية بالابتداء في التلاوة & 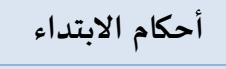 \\
\hline 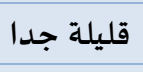 & .47 & 1.3 & يحسن الطالب المعلم أداء مهارات الروم & 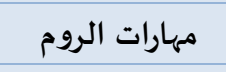 \\
\hline قليلة جدا & .42 & 1.2 & يحسن الطالب المعلم أداء مهارات الإشمام & 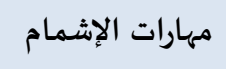 \\
\hline ق قليلة جدا & .67 & 1.5 & يجيد الطالب المعلم أداء مواضع النَّبر لدى التلاوة & \multirow{4}{*}{ مهارات النبَّد } \\
\hline قليلة & 1.3 & 2.4 & يجيد الطالب المعلم نطق المشـدَّد المفرد & \\
\hline متوسطة & 1.6 & 3.0 & يجيد الطالب المعلم نطق المشـدَّد الذي اجتمع فيه & \\
\hline قليلة & 1.2 & 1.8 & يجيد الطالب المعلم نطق المشـدَّد الذي اجتمعت فيه & \\
\hline فليلة & .97 & 2.0 & يتعرّف الطالب المعلم أخطاء التلاميذ لدى التلاوة & تعرُّف أخطاء \\
\hline قليلة & .97 & 2.0 & \multicolumn{2}{|c|}{ إجمالي ملاحظات أداء الطالب المعلم في تعليم التجويد وتلاوة القرآن الكريم } \\
\hline
\end{tabular}

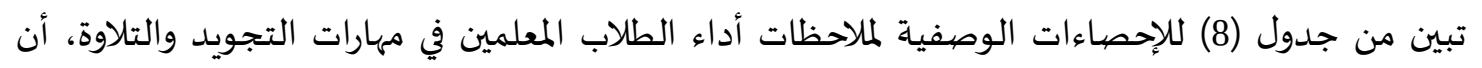
إجمالي نتائج الملاحظة حول مؤشرات أداء المهارات بين التمكن بدرجة متوسطة بنسبة (80.0\%)؛ وبدرجة قلئلة

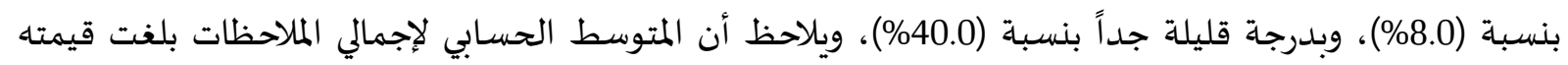

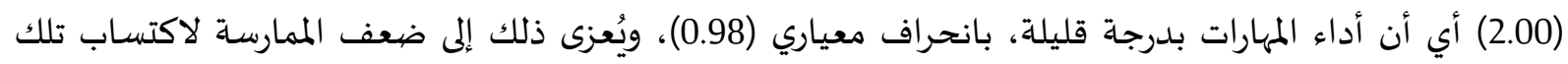

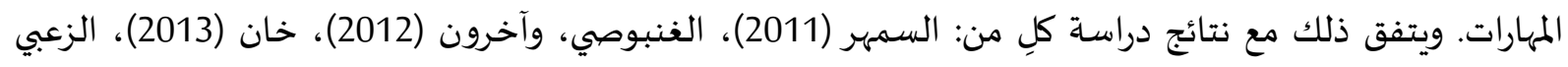
(2013)، والعصيل (2020) • الإجابة عن السؤال الثاني: "ما درجة تمكن الطلاب المعلمين من مهارات التجويد والتلاوة بتوصيف مقررات

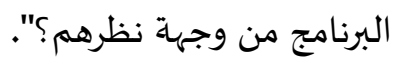


ولإجابة عن السؤال تم حساب المتوسط الحسابي، والانحراف المعياري، للإحصاءات الوصفية لدرجة تمكن

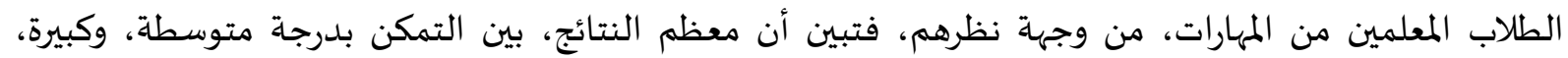
وكبيرة جداً، بمتوسط حسابي بلغ: (3.45).

جدول (9) درجة تمكن الطلاب المعلمين بالبرنامج من مهارات التجويد والتلاوة من وجهة نظرهم

\begin{tabular}{|c|c|c|c|}
\hline 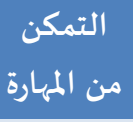 & 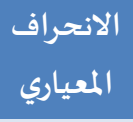 & الحتوسط المسابي & مؤشرات التمكن من مهارات التجويد والتلاوة \\
\hline كبيرة & 1.7 & 3.8 & نطق جميع الحروف مجودة في تلاوة القرآن \\
\hline 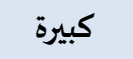 & .87 & 3.9 & نطق جميع الحروف نطقاً سليماً بمراعاة صفاتها \\
\hline كبيرة & 1.1 & 3.5 & إظهار النون الساكنة والتنوين عند ملاقاة لحروف:(الهمزة، الهاء، العين، الحاء، الغين، \\
\hline كبيرة & 1.6 & 3.6 & إظهار النون الساكنة مع حرفي الواو والياء في كلمة واحدة مطلقا (الدنيا، قنوان). \\
\hline كبيرة & 1.3 & 3.7 & إدغام النون الساكنة والتنوين بغنة عند ملاقاة الحروف:(الياء، النون، الميم، الواو). \\
\hline 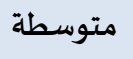 & 1.5 & 3.4 & إدغام النون الساكنة والتنوين بغير غنة عند ملاقاة حرفي: اللام والراء. \\
\hline كبيرة & .89 & 3.5 & 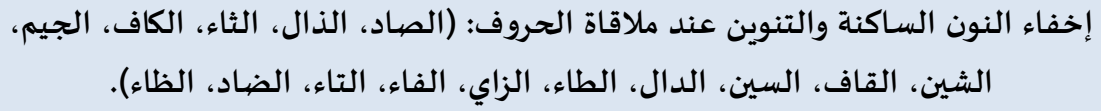 \\
\hline كبيرة & .95 & 4.1 & المعرفة التامَة بعدد حروف القلقلة \\
\hline كبيرة & 1.7 & 3.7 & قلقلة حروف " قطب جد " حال سكونها في الكلمة \\
\hline كبيرة & 1.4 & 3.6 & تفخيم حرف الراء في الكلمة حال سكونها \\
\hline كبيرة & 1.9 & 3.5 & ترقيق حرف الراء في الكلمة حال كسرها \\
\hline كبيرة & 1.3 & 4.00 & تفخيم لام لفظ الجلالة بعد فتح أوضم \\
\hline كبيرة & 1.2 & 3.4 & ترقيق لام لفظ الجلالة بعد كسر أو سكون. \\
\hline كبيرة & 1.2 & 3.4 & 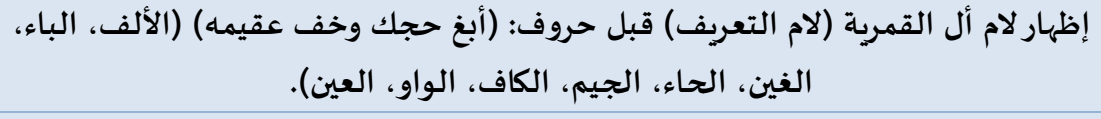 \\
\hline كبيرة & 1.6 & 3.5 & 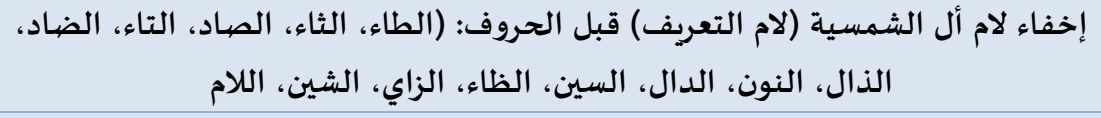 \\
\hline كبيرة & 1.2 & 4.1 & إظهار لام الفعل الساكنة في مواضعها المختلفة بالكلمة \\
\hline كبيرة & 1.8 & 3.8 & نطق الميم المشـددة بغنِّة \\
\hline كبيرة & .97 & 3.9 & نطق النون المشـددة بغنِّة \\
\hline كبيرة & 1.1 & 3.8 & 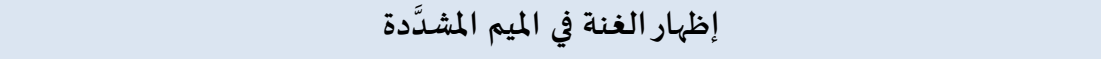 \\
\hline كبيرة & 1.4 & 3.7 & إظهار الغنة في النون المشـدَّدة \\
\hline كبيرة & .96 & 3.8 & إخفاء الميم السـاكنة عند ملاقاتها بحرف الباء \\
\hline كبيرة & 1.5 & 3.7 & إدغام الميم الساكنة عند ملاقاتها بحرف الميم \\
\hline
\end{tabular}


المجلة العربية للعلوم ونثر الأبحاث ـ مجلة العلوم التربوية والنفسية ـ المجلد الخامس ـ العلد الثاني ـ يناير 2021م

\begin{tabular}{|c|c|c|c|}
\hline من المهارة & الالنحراف & الحستوسط الحسبي & مؤشرات التمكن من مهارات التجويد والتلاوة \\
\hline 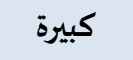 & 1.1 & 3.5 & إظهار الميم الساكنة عند التقائها بجميع حروف الهجاء عدا الباء والميم \\
\hline 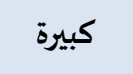 & 1.1 & 3.7 & إدغام الحرفين المتماثلين تماثلاً صغيراً \\
\hline 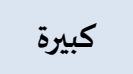 & 1.7 & 3.5 & إظهار الحرفين المتماثلين تماثلاً كبيراً أو مطلقاً \\
\hline كبيرة & .95 & 3.5 & إدغام الحرفين المتجانسين إن \\
\hline متوسطة & .90 & 3.3 & إدغام الحرفين المتقاربين إن \\
\hline 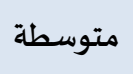 & 1.2 & 3.3 & إظهار الحرفين المتباعدين تباعداً صغيراً أو كبيراً مطلقاً. \\
\hline كبيرة & 1.4 & 3.7 & المعرفة الكافية بأنواع المدود \\
\hline 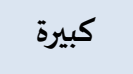 & 1.9 & 3.8 & نطق حروف المد الطبيعي بمقدار حركتين \\
\hline 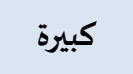 & 1.6 & 3.7 & نطق المد المتصل بمقدار أربع حركات أوخمس أوست \\
\hline 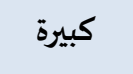 & 1.8 & 3.8 & نطق المد اللازم بمقدار ست حركات مع استثناء بعض مواضعه \\
\hline كبيرة & 1.2 & 3.6 & نطق المد المنفصل بمقدار أربع حركات أوخمس \\
\hline كبيرة & 1.2 & 3.5 & نطق مد الصلة الصغرى بمقدار حركتين بدقة \\
\hline كبيرة & 1.1 & 3.6 & نطق مد الصلة الصغرى نطقاً سليماً \\
\hline 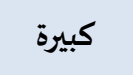 & 1.4 & 3.5 & نطق المد العارض للسكون قصراً (حركتين)أو توسطاً (أربعاً) أو إشباعاً (ستاً)بدقة \\
\hline 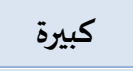 & 1.3 & 3.6 & المعرفة الدقيقة بمواضع السكت في القرآن الكريم \\
\hline 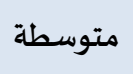 & 1.2 & 3.0 & نطق صهوت السكت نطقاً مجوداً \\
\hline 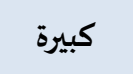 & 1.2 & 3.6 & 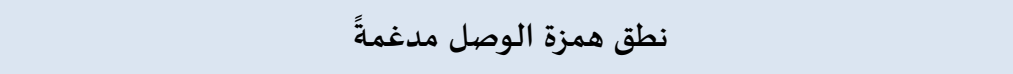 \\
\hline 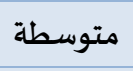 & 1.6 & 3.4 & نطق همزة القطع مظهرةً \\
\hline 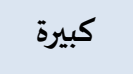 & 1.4 & 3.7 & أتعرُّف علامات الوقف في القرآن الكريم \\
\hline 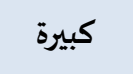 & 1.3 & 3.8 & تمييز علامات الوقف واصطلاحات الرسم بالمصاحف لدى التلاوة \\
\hline كبيرة & 1.3 & 3.5 & الوقوف على مواضع الوقف على الكلمة وقوفاً سليماً \\
\hline 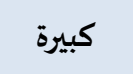 & 1.2 & 3.4 & الوقوف على حروف العلة وقوفاً سليماً \\
\hline متوسطة & 1.5 & 3.2 & نطق مواضع الوقف على التاء نطقا سليماً \\
\hline 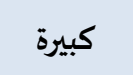 & 1.1 & 3.5 & نطق مواضع الوقف على الهاء نطقاً سليماً \\
\hline
\end{tabular}


المجلة العربية للعلوم ونثر الأبحاث ـ مجلة العلوم التربوية والنفسية ـ المجلد الخامس ـ العلد الثاني ـ يناير 2021م

\begin{tabular}{|c|c|c|c|}
\hline من المهارة & الالمعياري & الحستابي & مؤشرات التمكن من مهارات التجويد والتلاوة \\
\hline كبيرة & 1.7 & 3.6 & راعي مواضع الوقف الاختياري لدى التلاوةً \\
\hline كبيرة & 1.2 & 3.4 & مراعاة مواضيع الوقف الجائز لدى التلاوة \\
\hline كبيرة & 1.2 & 3.5 & الانتباه في التلاوة لمواضع الوقف القبيح \\
\hline كبيرة & 1.2 & 3.5 & المعرفة الكافية بالابتداء في التلاوة \\
\hline 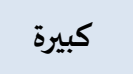 & 1.2 & 3.4 & نطق مواضع الابتداء نطقاً سليماً \\
\hline 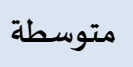 & 1.4 & 3.2 & التدريب على أداء الروم ضمن أحكام التجويد \\
\hline 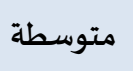 & 1.3 & 2.9 & التدريب على أداء الإشمام ضمن أحكام التجويد \\
\hline 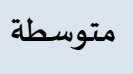 & 1.4 & 2.8 & مراعاة قاعدة الروم في مواضعه لدى التلاوة \\
\hline 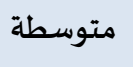 & 1.3 & 2.7 & مراعاة قاعدة الإشمام في مواضعه لدى التلاوة \\
\hline 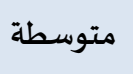 & 1.3 & 2.6 & النَّبر قاعدة من القواعد التجويدية \\
\hline 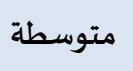 & 1.3 & 2.6 & يوجد النَّبر في كتب التجويد المشهورة \\
\hline 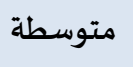 & 1.6 & 3.0 & الاهتمام بتطبيق مهارات النَّبر لدى التلاوة \\
\hline 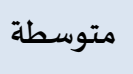 & 1.4 & 2.8 & توجد خطة واضحة للتدريب على أداء مهارات النَّبر على المستوى الشخصي \\
\hline 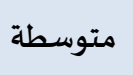 & 1.3 & 2.7 & نطق المشدَّد المفرد نطقاً سليماً \\
\hline 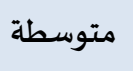 & 1.3 & 2.6 & نطق المشدّدد الذي اجتمع فيه حرفان مشدَّدان نطقاً سليماً \\
\hline 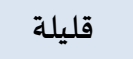 & 1.1 & 2.5 & نطق المشََّدد الذي اجتمع فيه ثلاثة مشـدَّدات متواليات بدقة \\
\hline 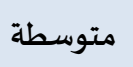 & 1.3 & 2.5 & نطق مواضيع الحركات والسكنات في التلاوة نطقاً سليماً \\
\hline 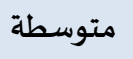 & 1.3 & 2.6 & تعرُف أخطاء القارئ في التلاوة حسب ورودها بدقة \\
\hline كبيرة & 1.1 & 3.4 & 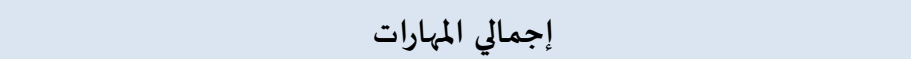 \\
\hline
\end{tabular}

تبين من الجدول (9) أن إجمالي نسبة نتائج إجابات الاستبانة حول تمكنهم من مهارات التلاوة من وجهة نظرهم، كانت: بدرجة متوسطة بنسبة (31.3\%)، ويُعزى ذلك إلى ضعف التهابـ التطبيق العملي، وتمكنهم بدرجة كبيرة

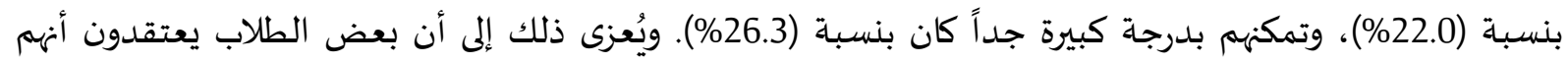

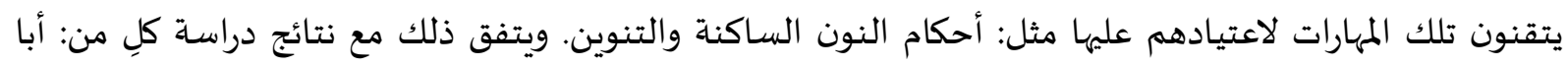
نمى (2009)، والمطرودي (2013). 
الإجابة عن السؤال الثالث: "ما درجة توافر مهارات التجويد والتلاوة في توصيف مقررات التجويد والتلاوة بالبرنامج؟". ولإجابة عن السؤال تم حساب المتوسط الحسابي، والانحراف المعياري، للمهارات اللازمة لتلاوة القرآن

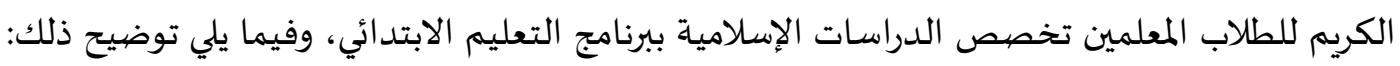

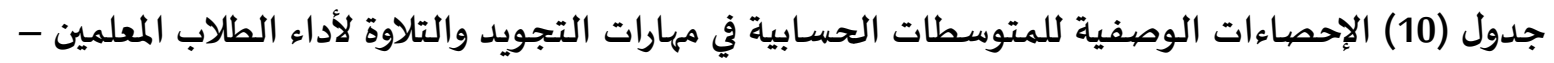
تخصص الدراسات الإسلامية-بالبرنامج

\begin{tabular}{|c|c|c|c|c|c|c|c|}
\hline درجة المهارة & ق أكبر & قيمة & 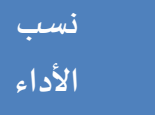 & الإنحرافات & المتوسطات & العبارات & مؤشرات أداء المهارات \\
\hline بدرجة كبيرة & 3.9 & 3.8 & $77 \%$ & 0.06 & 3.8 & 2 & المخارج والصفات \\
\hline$/ / / /$ & 3.7 & 3.4 & $71 \%$ & 0.13 & 3.5 & 5 & النون الساكنة والتنوين \\
\hline$/ / / /$ & 4.1 & 3.7 & $78 \%$ & 0.25 & 3.9 & 2 & القلقلة \\
\hline$/ / / /$ & 4.0 & 3.4 & $72 \%$ & 0.26 & 3.6 & 4 & التفخيم الترقيق \\
\hline$/ / / /$ & 3.5 & 3.4 & $69 \%$ & 0.10 & 3.4 & 2 & 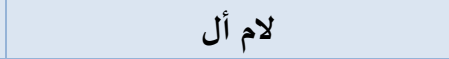 \\
\hline$/ / / /$ & 4.1 & 4.0 & $81 \%$ & & 4.0 & 1 & ل لام الفعل \\
\hline // // & 3.9 & 3.7 & $77 \%$ & 0.12 & 3.8 & 2 & الميم والنون المشددتين \\
\hline$/ / / /$ & 3.8 & 3.4 & $75 \%$ & 0.17 & 3.7 & 5 & الميم الساكنة \\
\hline$/ / / /$ & 3.7 & 3.3 & $70 \%$ & 0.17 & 3.4 & 5 & الحرفين المتقاربين والمتماثلين \\
\hline$/ / / /$ & 3.8 & 3.5 & $74 \%$ & 0.12 & 3.6 & 8 & أحكام المد \\
\hline متوسطة & 3.6 & 3.0 & $66 \%$ & 0.45 & 3.3 & 2 & مواضع السكت \\
\hline بدرجة كبيرة & 3.6 & 3.4 & $70 \%$ & 0.12 & 3.5 & 2 & همزة الوصل همزة القطع \\
\hline$/ / / /$ & 3.8 & 3.2 & $71 \%$ & 0.20 & 3.5 & 11 & واصطلاحات الرسم بالمصياحف وعلاماته والابتداء \\
\hline متوسطة & 3.2 & 2.7 & $59 \%$ & 0.21 & 2.9 & 4 & الروم والإشمام \\
\hline // // & 3.0 & 2.5 & $54 \%$ & 0.16 & 2.7 & 7 & المشَّدَدات والنبر \\
\hline بدرجة ضعيفة & 2.5 & 2.5 & $51 \%$ & 0.0 & 2.5 & 1 & الحركات والسكنات \\
\hline // // & 2.6 & 2.6 & $52 \%$ & 0.0 & 2.6 & 1 & تعرُّف الأخطاء في التلاوة \\
\hline بدرجة كبيرة & 4.1 & 2.5 & $69 \%$ & 0.41 & 3.4 & 64 & المجموع الكلي لمتوسطات مهارات \\
\hline \multicolumn{8}{|c|}{ جدول (11) تحليل التباين(ANOVA) () لاختبار الفرض الأول } \\
\hline \multicolumn{2}{|c|}{ القيمة الاحتمالية } & قيمة (ف) & متوسطات & 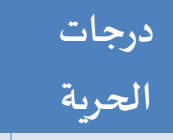 & | مترموع |لمربعات | & \multicolumn{2}{|c|}{ التباينات بين متوسطات مؤشرات } \\
\hline \multirow{2}{*}{\multicolumn{2}{|c|}{.000}} & \multirow{3}{*}{16.3} & 0.5 & 16 & 8.9 & & التباينات بين المجموعات \\
\hline & & & 0.3 & 47 & 1.6 & & التباينات داخل المجموعات \\
\hline & & & & 63 & 10.5 & & المجموع \\
\hline
\end{tabular}


يلاحظ من جدول (10) لمؤشرات أداء المهارات، و(11) لتحليل التباين (ANOVA) لاختبار الفرض الأول، أن التباينات بين متوسطات مهارات التجويد وتلاوة القرآن الكريم، كانت قيمة مجموع مربعات التباينات بين المجموعات (8.9) بدرجات حرية (16) ومتوسطات المربعات للتباينات بين المجموعات (0.56). أما مجموع مربعات التباينات داخل

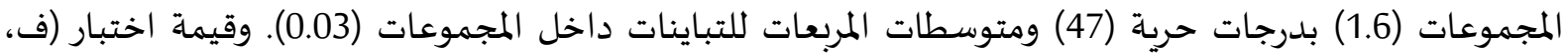
F=F_=F بقيمة احتمالية (0.000) أقل من القيمة المعنوية 0.05 وهذا يشير إلى وجود فرق بين متوسطات مؤشرات مهارات التجويد والتلاوة اللازمة لطلاب تخصص الدراسات الإسلامية بالبرنامج تعزى لضعف تمكنهم من تلك المهارات وقبول الفرض القائل بذلك. كما تم حساب التكرارات لبيانات تحليل المحتوى التعليمي محل الدراسـ، فكانت النتائج كالتالي:

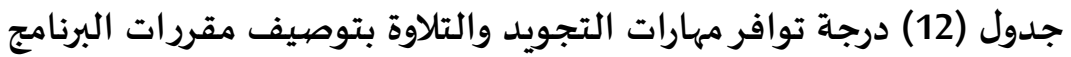

\begin{tabular}{|c|c|c|c|c|c|c|}
\hline \multirow{2}{*}{ المجموع } & \multicolumn{5}{|c|}{ تكرارات توافر مهارات التجويد والتلاوة بتوصيف مقررات البرنامج } & \multirow{2}{*}{ مهارات التجويد والتلاوة } \\
\hline & بدا جداً & قليلة & 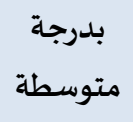 & 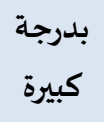 & كبيرة جدراً & \\
\hline 2 & - & - & - & - & 2 & مدخل لعلم التجويد \\
\hline 2 & - & 2 & - & - & - & المخارج والصفات \\
\hline 1 & - & 1 & - & - & - & القلقلة \\
\hline 4 & - & 4 & - & - & - & 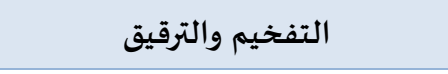 \\
\hline 2 & - & 2 & - & - & - & 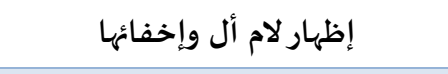 \\
\hline 1 & - & 1 & - & - & - & 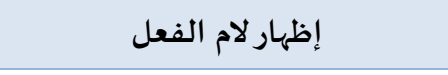 \\
\hline 6 & - & 6 & - & - & - & 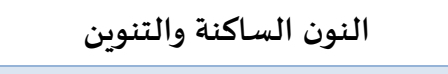 \\
\hline 2 & - & 2 & - & - & - & الميم والنون المشـدَّدتين \\
\hline 3 & - & 3 & - & - & - & 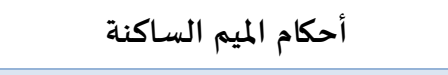 \\
\hline 5 & - & 5 & - & - & - & 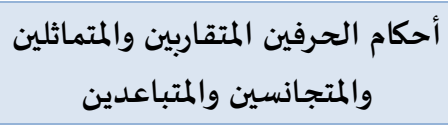 \\
\hline 8 & - & 8 & - & - & - & 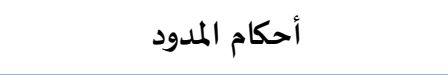 \\
\hline 1 & - & 1 & - & - & - & 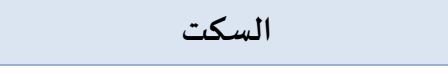 \\
\hline 2 & - & 2 & - & - & - & 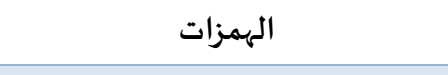 \\
\hline 8 & 4 & 4 & - & - & - & الوقف والرسم والابتداء \\
\hline 2 & 2 & - & - & - & - & 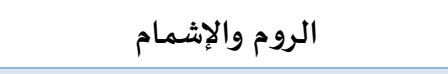 \\
\hline 3 & 3 & - & - & - & - & المشـدَّدات \\
\hline 4 & - & - & - & 4 & - & ثانياً: تطبيقات تلاوة القرآن الكريم \\
\hline & 11 & 39 & صفر & 4 & 2 & المجموع \\
\hline
\end{tabular}

يلاحظ من الجدول (12) قلة التكرارات حول توافر بعض مهارات التجويد والتلاوة بتوصيف مقررات البرنامج، وخاصة في: المخارج والصفات، القلقلة، إظهار لام الفعل، أحكام الميم والنون المشددتين، أحكام الميم 
الساكنة، الروم والإشمام، والمشـددات والنبر، وقبول فرضيته. ويتفق ذلك مع نتائج دراسة كلٍ من: الجمل (2011)،

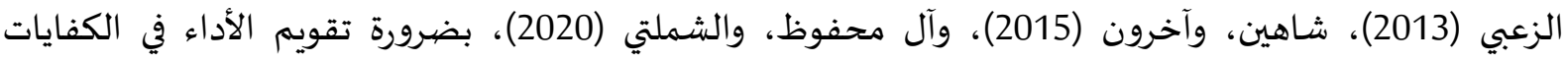

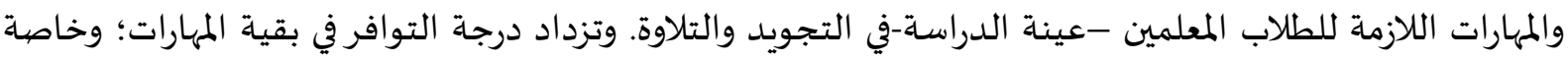

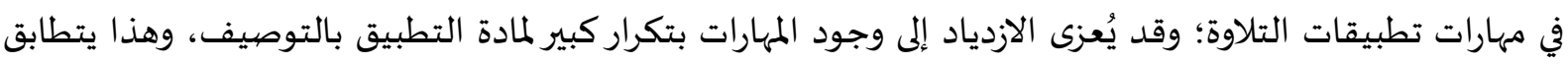

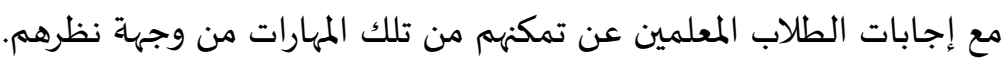

البرنامج الإثرائي المقترح لتنمية مهارات التجويد والتلاوة لدى الطلاب المعلمين بكلية التربية في جامعة بيشة:

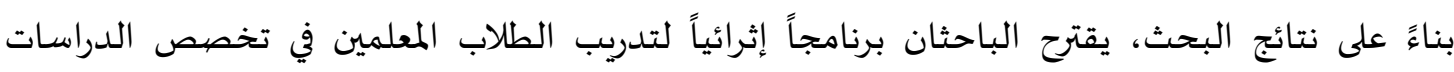

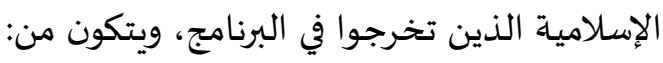

أهدف البرنامج: يتوقع بعد الانتهاء من هذا البرنامج الإثرائي، أن يكون الطالب المعلم قادراً على: - - توضيح مفهوم مد الصلة الصغرى وتطبيقاته في التلاوة.

تحديد مواضع الحركات والسكنات في التلاوة.

تعرف السكت وتطبيقاته في القرآن الكريم.

- - الوقف على همزتي الوصل والقطع وتطبيقاتهما في التلاوة.

تحديد مواضع الوقف على الهاء وتطبيقاتها في التلاوة.

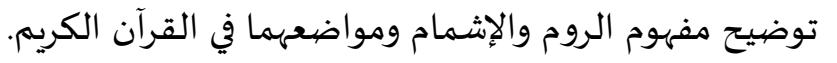

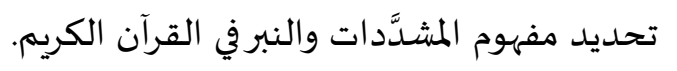
تعرُّف أخطاء التلاوة في القرآن الكريم.

زمان التدريب ومكانه: يقترح أن تقدم هذه القائمة في شكل أنشطة إثرائية مفتوحة بواقع ساعتين، لكل موضوع ولمدة شهر، بإشراف قسم الدراسات الإسلامية.

جدول (13) القائمة الإثرائية بمهارات التجويد والتلاوة والساعات اللازمة لكل موضيوع ومكان تنفيذه:

\begin{tabular}{|c|c|c|c|}
\hline 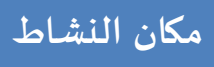 & 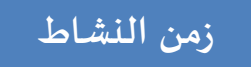 & الموضيوع & $\hat{r}$ \\
\hline \multirow{8}{*}{ مختبر اللغة } & \multirow{8}{*}{ سـاعتان في اليوم } & مد الصلة الصغرى & 1 \\
\hline & & مواضع الحركات والسكنات في التلاوة & 2 \\
\hline & & 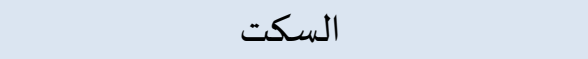 & 3 \\
\hline & & همزتا الوصل والقطع & 4 \\
\hline & & مواضع الوقف على الهاء & 5 \\
\hline & & الروم والإشمام & 6 \\
\hline & & المشـدَّدات والنبر في القرآن الكريم & 7 \\
\hline & & تعرُّف أخطاء التلاوة في تلاوة القرآن الكريم & 8 \\
\hline
\end{tabular}

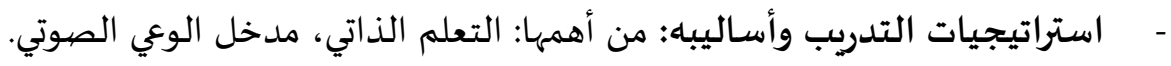

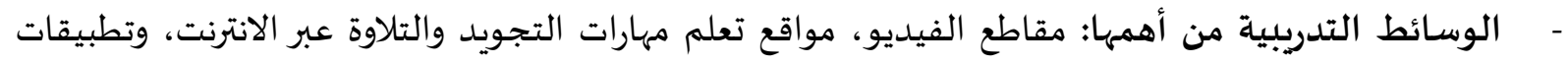

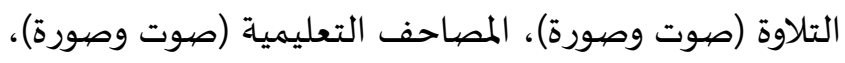


تقويم البرنامج: يُقوّم البرنامج من خلال: عروض تقديمية (تدريب مصغر)، استمارة تقويم الطلاب المعلمين التي

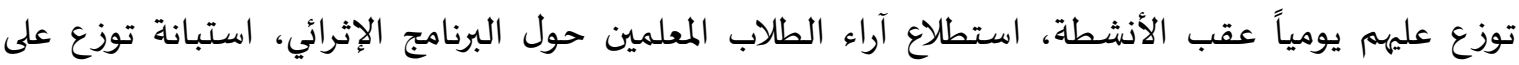
الطلاب المعلمين في نهاية البرنامج، ملفات الأعمال.

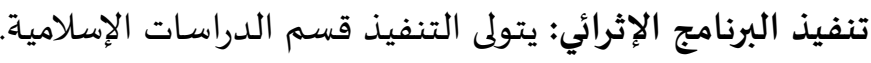
- - الجهاة المقدمة للبرنامج: قسم المناهج وطرق التدريس بكلية التربية بالتنسيق مع الجهات المعنية. 5. التوصيات والمقترحات: استنادا لنتائج البحث يوصي الباحثان ويقترحان الآتي:

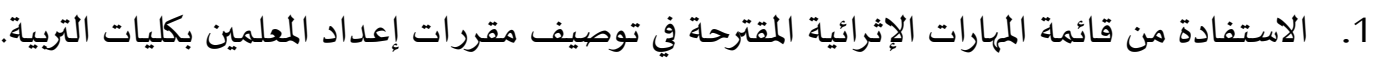

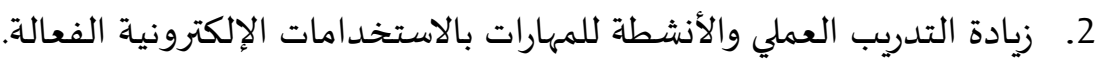

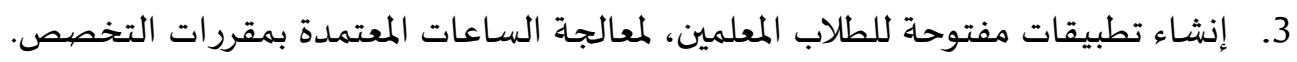

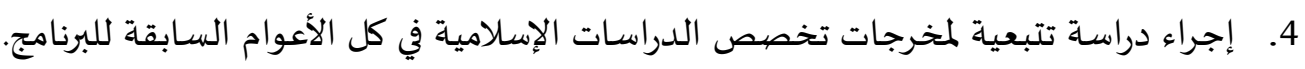
5. إجراء بحوث تقويمية لبرامج إعداد الطلاب المعلمين النظيرة في الدراسات الإسلامية.

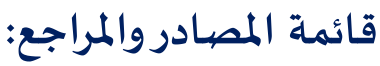

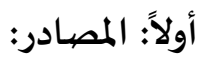

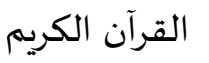
- البخاري، محمد بن إسماعيل (1422هـ)، صحيح البخاري، تحقيق: الناصر، محمد زهير، دار طوق النجاة، ترقيم محمد فؤاد عبد الباقي، مصر، القاهرة.

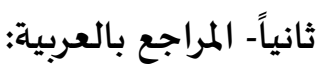

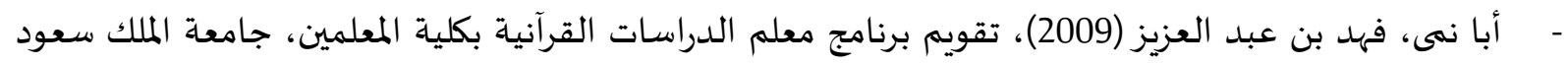

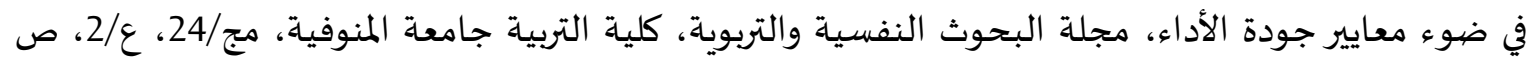

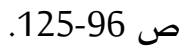
ابن الجزري، شمس الدين أبو الخير، (د. ت)، مراجعة: الضباع، علي محمد، النشر في القراءات العشر، ج/125، دار الكتب العلمية، بيروت، لبنان. أبو الرب، عماد، وآخرون (2010)، ضمان الجوان الجودة في التعليم العالي، دار صفاء، الأردن.

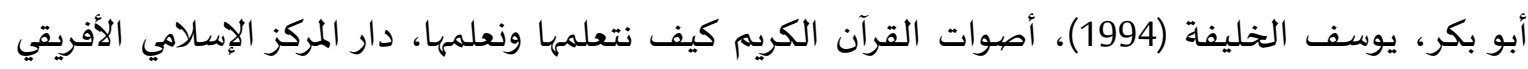

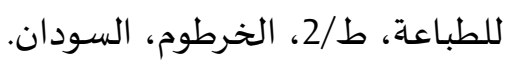
أحمد، أحمد علا عبد الرحيم سيد (2008)، تطوير برامج إعداد المعلم المعاد في كليات التربية في ضوء بعضو بعض معايير

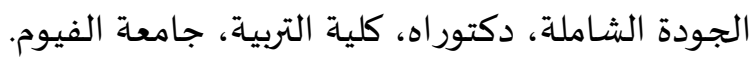

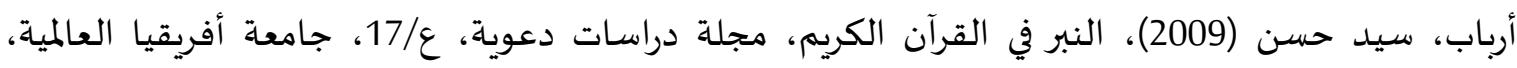

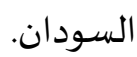
الأكلبي، مفلح دخيّلّ (2017)، المرجع الحديث في تدريس مقررات التربية الإسلامية (المفاهيم والتطبيقات)، مكتبة الرشد، الرياض، السعودية. (2017) المرجع. 
آل محفوظ، والشملتي (2020)، درجة امتلاك معلمي التربية الإسلامية بالمرحلة الابتدائية للكفايات التدريسية اللازمة كم وجها نظر المشرفين التربويين وقادة المدارس بالمملكة العبية السعودياة، مجلة الجامعة الإسلامية

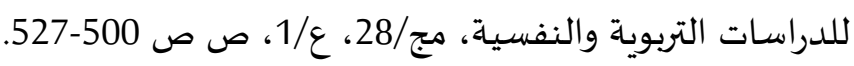

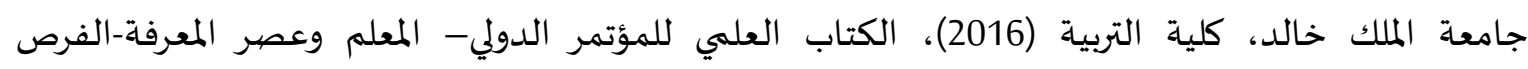

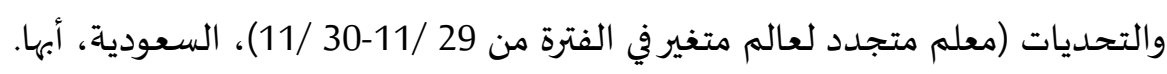

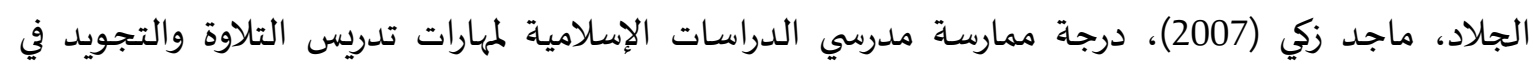

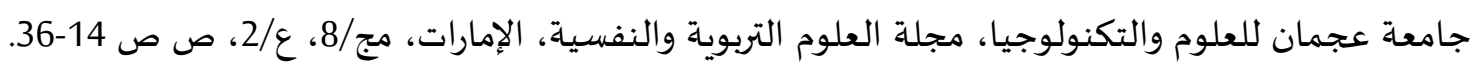

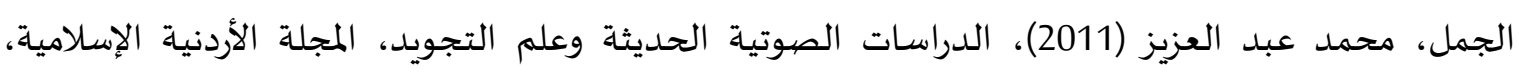

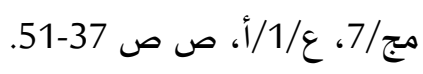
حلس، داود بن درويش (2010)، محاضرات في طرائق تدريس التربية الإسلامية، ط/3/10، متاحاً بتاريخ 20/ 6 2020/ ال20/

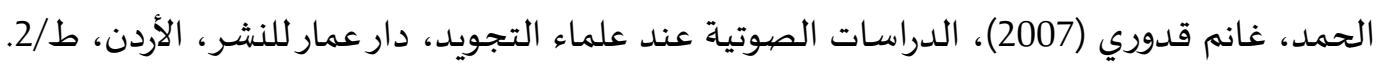

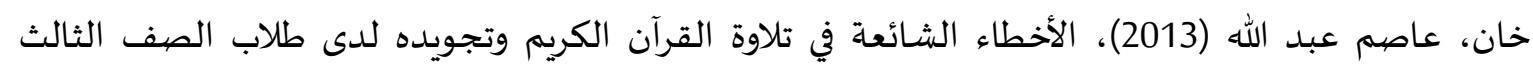

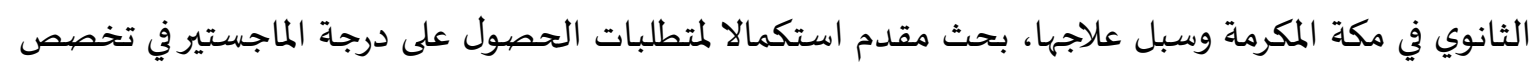
المناهج وطرق تدريس التربية الإسلامية، جامعة أم القرى، كلية التربية.

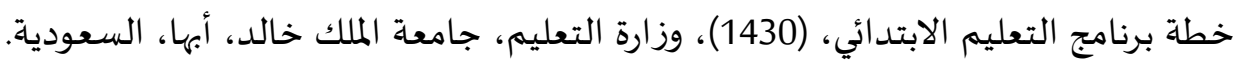

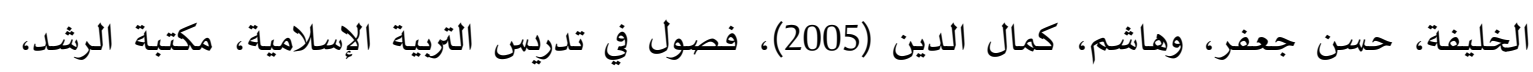
الرياض، السعودية.

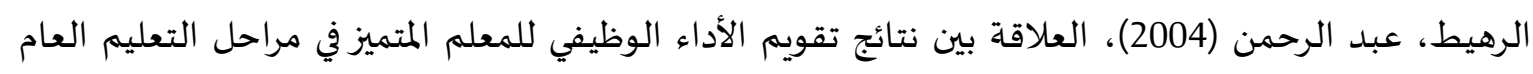

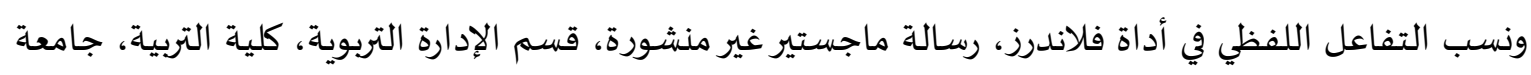
الملك سعود، الرياض.

الزعبلاوي، محمد السيد (1420هـ)، طرق تدريس القرآن الكريم، مكتبة التوبة، الرياض، السعودية.

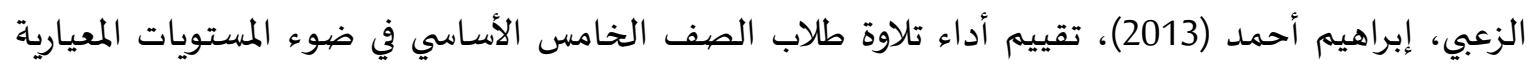

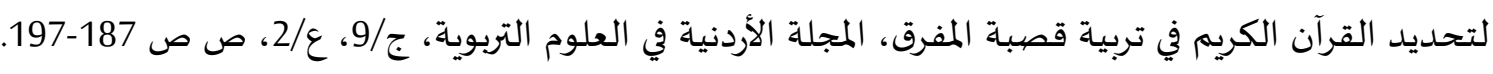

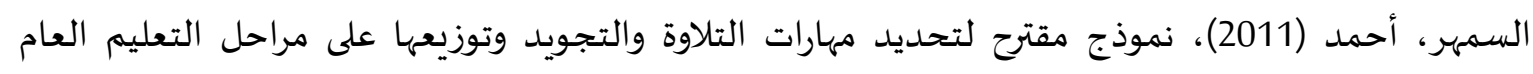

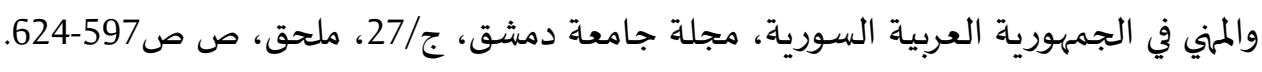

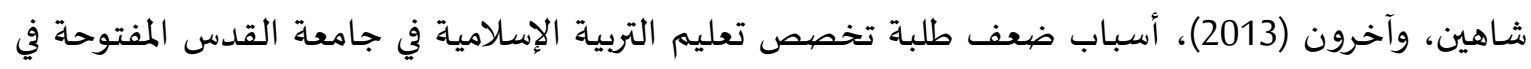

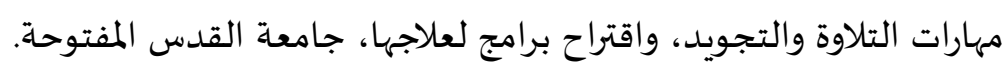
الشراري، سلامة منزل (2017)، الكفايات الفنية الواجب توفرها لدى معلمي التربية الإسلامية، مجلة دوراسلة دراسات

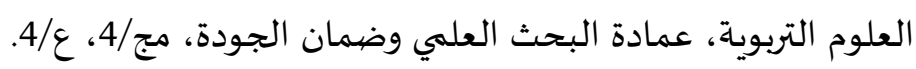

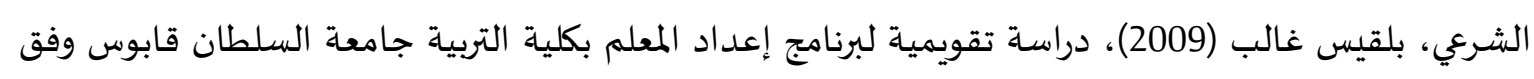

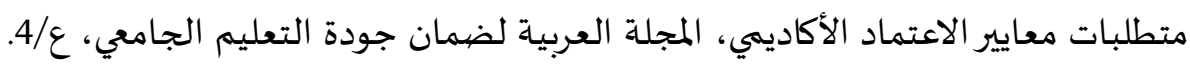
طعيمة، رشدي أحمد (1999)، تحليل المحتوى في العلوم الإنسانية، القاهرة، دار الفكر العربي.

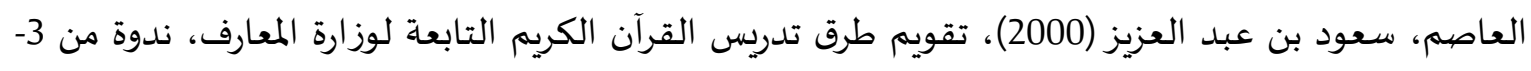
1421/7/6هـ، مجمع الملك فهد لطباعة المصحف الشريف، وزارة الشؤون الإسلامية، المدينة المنورة. 
- - العالم، عثمان محمد حامد (2006)، طرق وأساليب تدريس القرآن الكريم أسس نظرية ونماذج تطبيقية، مكتبة الرشـد، الرياض، السعودية.

عطا، إبراهيم محمد (2009)، المرجع في التربية الإسلامية، القاهرة، مركز الكتاب للنشر.

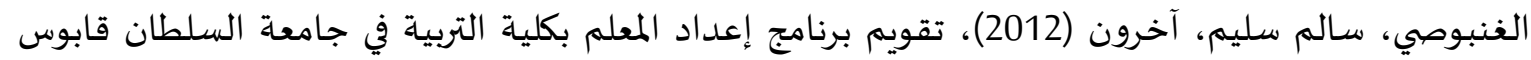

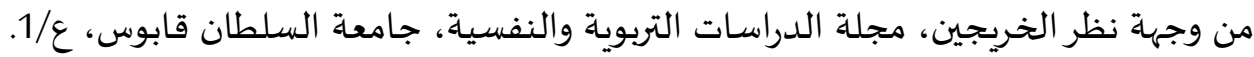

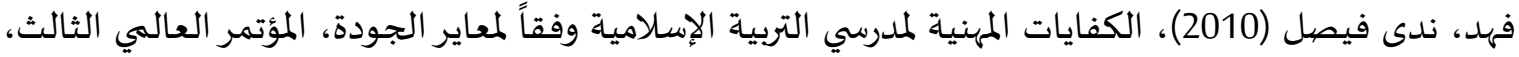
تربية المعلم وتأهيله، رؤى معاصرة، كلية العلوم التربوية، جامعة جرش الأهلية.

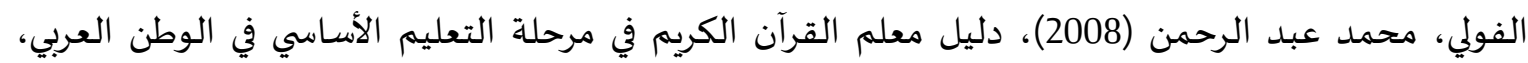
تونس، المنظمة العربية للتربية والثقافة والعلوم. الكسباني، محمد السيد علي (2010)، المنهج المدرسي المعاصر بين النظرية والتطبيق، مؤسسة حورس الدولئه للنشر، الإسكندرية، مصر. الكلثم، حمد بن مرضي (2013)، تقويم أداء معلم التربية لإسلامية في المرحلة المتوسطة في ضوء نموذج أبعاد

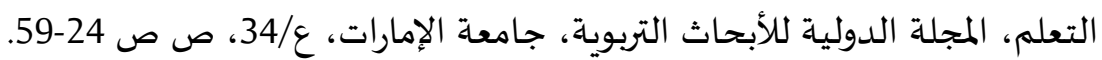
الكلثم، حمد مرضي إبراهيم (2008)، بناء الإعداد التربوي لمعلم التربية الإسلامية وفق الاتجاهاتهات الماتهات الحديثة

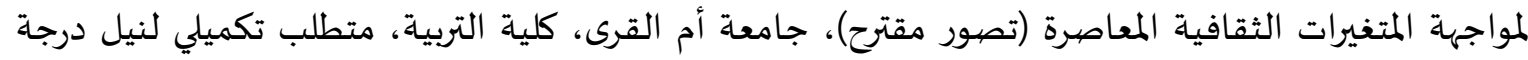
الدكتوراه في المناهج وطرق تدريس التربية الإسلامية.

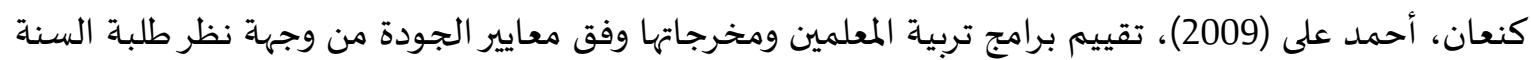

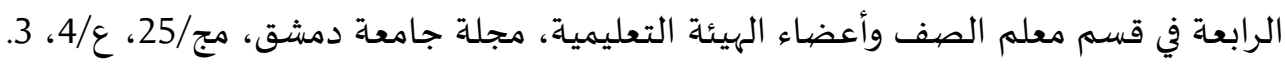

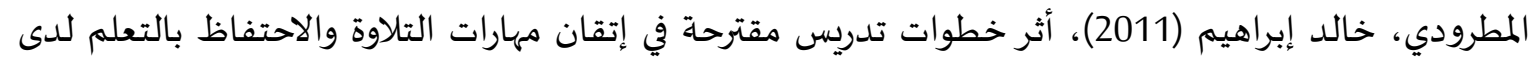

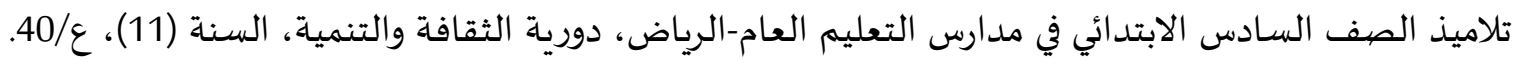
المعجل، طلال محمد (2001)، تقويم مستوى طلاب الدراسات الإسلامية في تلاوة القرآن الكريم في بعض كلئ كليات دول مجلس التعاون الخليجي وعلاقة ذلك ببعض المتغيرات، مجلة دراسات في المناهج وطرق التدريس، ع/20، ص ص نصر، عطية قابل (2014)، غاية المريد في علم التجويد، مكتبة دار الأبرار، مصر.

ثالثاً- المراجع بالإنجليزية:

- Dean, C. B. L., \& Patricia A. (2003). Systematic Evaluation for Continuous Improvement of Teacher Preparation. Volum, 2: Case summary Report. USA.

- Lewis, Mark \& Kraus, Larry (2009). Teaching Competencies o Students Completing Traditional and Certification - Only Teacher Education Programs, ERIC - Education Resources Information Center, (E)403232). 